\title{
Drivers of land use change and household determinants of sustainability in smallholder farming systems of Eastern Uganda
}

\author{
Peter Ebanyat • Nico de Ridder • Andre de Jager • \\ Robert J. Delve $\cdot$ Mateete A. Bekunda $\cdot$ Ken E. Giller
}

Published online: 6 March 2010

(C) The Author(s) 2010. This article is published with open access at Springerlink.com

\begin{abstract}
Smallholder farming systems in sub-Saharan Africa have undergone changes in land use, productivity and sustainability. Understanding of the drivers that have led to changes in land use in these systems and factors that influence the systems' sustainability is useful to guide appropriate targeting of intervention strategies for improvement. We studied low input Teso farming systems in eastern Uganda from 1960 to 2001 in a place-based analysis combined with a comparative analysis of similar low input systems in southern Mali. This study showed that policy-institutional factors next to population growth have driven land use changes in the Teso systems, and that nutrient balances of farm households are useful indicators to identify their sustainability. During the period of analysis, the fraction of land under cultivation increased from 46 to $78 \%$, and communal grazing lands nearly completely disappeared. Cropping diversified over time; cassava overtook cotton and millet in importance, and rice emerged as an alternative cash crop. Impacts of political instability, such as the collapse of cotton marketing and land management institutions, of communal labour arrangements and aggravation of cattle rustling were linked to the changes. Crop productivity in the farming systems
\end{abstract}

P. Ebanyat $(\bowtie) \cdot$ M. A. Bekunda

Department of Soil Science, Makerere University, P.O. Box 7062, Kampala, Uganda

e-mail: ebanyat@agric.mak.ac.ug

N. de Ridder · K. E. Giller

Plant Production Systems Group, Wageningen University, P.O. Box 430, 6700 AK Wageningen, The Netherlands
A. de Jager
Wageningen University and Research Centre-Agricultural Economics Research Institute (LEI),
P.O. Box 29703, 2502 LS Den Haag, The Netherlands

\section{R. J. Delve}

Tropical Soil Biology and Fertility Institute of International Centre for Tropical Agriculture (TSBF-CIAT), P.O. Box 30677-00100, Nairobi, Kenya 
is poor and nutrient balances differed between farm types. Balances of $\mathrm{N}, \mathrm{P}$ and $\mathrm{K}$ were all positive for larger farms (LF) that had more cattle and derived a larger proportion of their income from off-farm activities, whereas on the medium farms (MF), small farms with cattle (SF1) and without cattle (SF2) balances were mostly negative. Sustainability of the farming system is driven by livestock, crop production, labour and access to off-farm income. Building private public partnerships around market-oriented crops can be an entry point for encouraging investment in use of external nutrient inputs to boost productivity in such African farming systems. However, intervention strategies should recognise the diversity and heterogeneity between farms to ensure efficient use of these external inputs.

Keywords Population growth · Political instability - Land use change · Nutrient balances · Farm typology · Sub-Saharan Africa

\section{Introduction}

Land use change in African farming systems is attributed to population growth which is commonly blamed for widespread environmental degradation (Cleaver and Schrieber 1994). This ascribes to the neo-Malthusian theory that once carrying capacity of the land resources has been surpassed degradation occurs (Malthus 1989). There are, however, cases where environmental quality has been reported to improve with population growth (Tiffen et al. 1994; Tappan and McGahuey 2007) in line with Boserup's (1965) theory of technological innovations with population increase. Population growth alone is insufficient to explain land use change in most tropical farming systems - rather, it interacts with other underlying factors such as politics and cultural norms and economic climate prevailing in a given geographical location (Lambin et al. 2001, 2003). Thus depending on the prevailing socioeconomic factors and household resource conditions, farming systems may undergo intensification or extensification (Crowley and Carter 2000; Malmberg and Tegenu 2007; Siren 2007).

Land use and land cover in the Teso farming system in eastern Uganda has changed over the last decades. The farming system is a mixed agro-pastoral system based on production of annual crops and livestock for subsistence that supports onefifth of the national population. In the 1960s, the dominant annual cropping systems were cotton-millet (Parsons 1970) but these have been overtaken in importance by cassava from the mid 1990s. Widespread soil degradation (Wortmann and Kaizzi 1998; Walaga et al. 2000; Nkonya et al. 2005), wetland encroachment (NEMA 2001) and low crop productivity in the system (Kidoido et al. 2002) are reported. Livelihoods of the smallholders are threatened and recurrent episodes of famine have occurred (Ssali et al. 2002).

The drivers of the population-farming-environment interactions in this system are not well understood yet are vital in guiding how to intervene. Studies on such a nexus in African farming systems usually have empirical evidence based on correlations of between land use and population growth but commonly use inferential analysis to derive the influence of policy and institutional factors (Mango 
1999; Hamandawana et al. 2005; Baijukya et al. 2005; Kamusuko and Aniya 2007). This study uses a place-based analysis combined with a comparative case study analysis (Lambin et al. 2003) to identify the underlying policy-institutional factors, which in addition to population growth, have resulted in the land use change in the Teso farming system. The cotton-cereal farming system of southern Mali is used as a case study system because of similar biophysical environmental conditions with those of the Teso system. Both systems have experienced population increases during the period of analysis (1960-2001) with cotton being the major source of income. Cotton remained a major source of income in the Mali system and productivity of the farming system improved with time. Cotton yields were raised from 0.23 to over $1 \mathrm{t} \mathrm{ha}^{-1}$ and those for cereals from 0.7 to $1 \mathrm{t} \mathrm{ha}^{-1}$ (Benjaminsen 2001; Tefft 2004). The Malian system has enjoyed political stability at least relative to Uganda and institutional support remained stable over time (Bingen 1998) whilst the Ugandan system has operated under political instability with no supportive institutions. In this way we are able to identify policy-institutional factors that have influenced the Teso system.

Land use and land cover observed on landscapes is a reflection of aggregated land use decisions at the household level (Perz 2001; Lambin et al. 2003; Browder et al. 2004). Land use and cover changes and environmental quality, however, are also associated (Nepstad et al. 1999; Fearnside 2000) particularly with the management practices applied on given land use types. Empirical relationships that are explored are mainly interactions between household characteristics, socioeconomics and land use (Pichón 1997; Perz 2001; Browder et al. 2004; VanWey et al. 2007) but hardly with soil quality (Nkonya et al. 2005).

Soil fertility and hence productivity is related with soil nutrients, i.e. mineral elements in soils required by plants to complete normal growth (essential elements). Three of the 20 essential elements are usually required by plants in large amounts for normal growth, namely nitrogen $(\mathrm{N})$, phosphorus $(\mathrm{P})$ and potassium $(\mathrm{K})$. They are also the major nutrients limiting crop production in sub-Saharan African farming systems (Vlek 1990). Balances of these nutrients in agro-ecosystems can indicate the sustainability status of the farming system (Van der Pol and Traore 1993). Relating them with farm household characteristics can therefore help to identify factors that influence sustainability of farming systems, an approach we apply in this study. Although static, nutrient balances are a reflection of management practices that influence movement (flows) of nutrients into, within and out of a given farming system and therefore reflect aggregated management decisions of different farm types in response to prevailing policy-institutional environments (Defoer and Budelman 2000). Nutrient balances are computed as the difference between total nutrient inflows and total nutrient outflows and can be measured at various spatial scales ranging from plant, plot, field, farm, community, regional, national and continental (De Jager et al. 1998).

This study adds to the only one so far known for an African farming system that explored such relationships for identification of regional policy interventions (Nkonya et al. 2005). Furthermore, our study recognises the diversity in farm households and heterogeneity in soil fertility within farming systems (Tittonell 2007), which have been ignored in developing recommendations and yet are 
important to farmers in deciding how to use the land and which management practices to adopt (Smaling 1993). The objectives of this study are therefore: (i) to identify the drivers of land use change in the Teso farming system from 1960 to 2001 and its impacts on soil productivity; and (ii) to determine the farm-level factors that influence farming systems' sustainability. The subsequent sections of this article are organised as follows: literature review on farming systems and land use decisions; description of the study area and sites used; procedures of data collection for land use and land cover and farm surveys to obtain farm characteristics; farmers perceptions on soil productivity and nutrient management data including nutrient flows; statistical data analysis; results and discussion and lastly conclusions and future directions for improvement of the system.

\section{Land use dynamics and farming systems sustainability}

Spatial temporal patterns in land use observed at high scales are an aggregation of land use and management decisions at micro-scale by households in response to policy and institutional environment over time (Lambin et al. 2003). As households are diverse in terms of resources and operate within heterogeneous biophysical and policy and institutional environments, the land use patterns exhibit spatial and temporal dynamics (Dixon et al. 2001). To explain patterns of land use and land cover changes, studies have built on the Chayanovian theory, which used the household demographic cycle to explain the differences in land areas cultivated by households in peasant farming systems in Russia (Thorner et al. 1986). Households with lower dependency ratios (more labour units compared to consumer units) cultivated more land than those with higher dependency ratios. The dependency ratios, however, change with maturation of households and so with land use (Perz 2001). This theory holds under assumptions of land abundance, absence of labour markets, and no input credit and output markets (Perz 2001), conditions that do not hold for most tropical farming systems.

The concept has been modified to include labour markets, access to input and output markets in addition to the household demographic structures and mainly tested in the Amazon forest frontiers (conditions of land abundance still exist) to empirically explain the changes in deforestation based on relationships between ways of using land and household demographic characteristics (Browder et al. 2004), and in few cases internal and external factors influencing farm households decisions on land use (Pichón 1997; VanWey et al. 2007). Generally, household's internal demands for survival and subsistence in the context of prevailing socio-economic and political environment determine choice for land use (Walker et al. 2002).

Several factors have been used to explain land use decisions including soil quality, farm size, farm labour, level of household education, farming experience, land tenure security, distance to market, farm age, off-farm income, participation, initial wealth status of households, access to credit, and technical knowledge (Browder et al. 2004). No consistent effects of these independent variables were usually observed in terms of relationships between land use and household characteristics. Pichón (1997) working in the Ecuadorian Amazon found soil 
fertility, topographical location of farmland, the duration of settlement (farm age) and household resource endowments to significantly influence land use decisions. Owners of larger cattle herds left large farm areas under pasture and decreased the share of farm area allocated to food crops. Smaller farms used land more intensively and cleared most of the forest for annual and perennial cropping. Families with larger farms cleared less proportions of forests; pastures and this was more important on the larger rather than the small farms and closely related to ranching land use. Further, farm household demographic characteristics such as education level of household head, family and wage labour, and consumer units had significant effects on land use decisions. Security of land tenure also significantly influenced land-allocation decisions. Farm households with land titles converted less forest to agricultural land and had smaller shares of farm area cultivated in perennial and food crops and pastures than households without formal tenure. Perz (2001) also found that demographic household variables, the institutional context, off-farm income, farmers' background and belonging to groups (neighbourhood context) exerted significant effects on land use. By contrast, VanWey et al. (2007) found that cropping activities depended mainly on women and children for labour provision and not on men as reported by Pichón (1997). They also found that strategies for accessing cash for investment in farming were important in influencing cropping activities. Browder et al. (2004) found only farm size to be important in influencing decisions on annual and perennial cropping. Larger farms allocated more land to pasture and cattle ranching than small size farms. They found no significant effects of household demographic characteristics, gender and age (except total family size) nor of policy environment factors (access to technical assistance, off-farm incomes) on land use. This contradicts the findings of Pichón (1997), Perz (2001) and VanWey et al. (2007) who argued that the household life cycle influenced land use decisions. Such mixed responses suggest that investigations of household land use decisions are context-specific to regions, which was an impetus for us to apply the approach to low-input subsistence farming systems in Africa.

Nkonya et al. (2005) demonstrated that household demographic characteristics, resource endowments and policy-institutional factors affect management of nutrient inputs in smallholder farming systems. However, households are diverse and cannot be classified solely on land use (Browder et al. 2004). Classifying farmers using functional typologies on the basis of their wealth characteristics, production orientations and livelihood strategies is more relevant when examining livelihood strategies (Tittonell et al. 2005). We take a step further to relate the characteristics distinguishing households, and soil productivity indicator, yield, with nutrient balances, to identify characteristics that determine sustainability (assessed using nutrient balances as indicators). Understanding of factors that influence sustainability can guide allocation and enhance efficient use of management resources.

\section{The study area}

Pallisa district $\left(1^{\circ} 43^{\prime} \mathrm{N}, 33^{\circ} 37^{\prime} \mathrm{E}\right)$ in eastern Uganda (Fig. 1), representative of the mixed annual crop-livestock Teso farming system supporting one-fifth of the 
population was selected for this study. Cotton and millet production were highest in this area in the 1960s (GOU 1962) and is an example of remarkable change in land use. The landscape is characterised by wide gently convex interfluves separated by wide swampy valleys (Ollier et al. 1969). The toposequence can be divided into three sub-zones; the upland zone at the summits (upper landscape positions), the midland zones located on pediments (middle landscape positions) and the valleys which may be seasonally or permanently wet (lower landscape positions). Soils on convex interfluves are derived from either lake deposits with Basement Complex rocks or from only Basement Complex rocks and gneisses (Harrop 1970). The soils on the uplands and midlands and in the valleys are, respectively, classified as Ferralsols and Fluvisols (Ebanyat 2009)

Mean annual rainfall (800-1200 mm) is distributed in a bimodal pattern. The first rains are from March to June with a peak in April and the second rains are from August to October or November with a peak in September or October. There are dry spells from November to March. Mean monthly temperatures range from 15 to $36^{\circ} \mathrm{C}$, with an annual mean of $25^{\circ} \mathrm{C}$ (Yost and Eswaran 1990). On the basis of spatial distribution of rainfall, however, the district is divided into four rainfall zones and the study area falls within a region of $900 \mathrm{~mm}$ per annum (Fig. 1).

Major crops grown include cassava (Manihot esculenta Crantz), finger millet (Eleusine coracana L. Gaertn), sorghum [Sorgum bicolor (L.) Moench], groundnut (Arachis hypogaea L.), cowpea [Vigna unguiculata (L.) Walp.], greengram [(Vigna radiata (L.) R. Wilczek], sweet potato (Ipomoea batatas Poir.), cotton (Gossypium hirsutum L.), and maize (Zea mays L.). Rice (Oryza sativa L.) is grown in the valleys. Crop production in the area is mainly limited by $\mathrm{N}$ and $\mathrm{P}$ (Wortmann and Eledu 1999). Livestock kept include cattle, sheep, goats, pigs and poultry. Annual

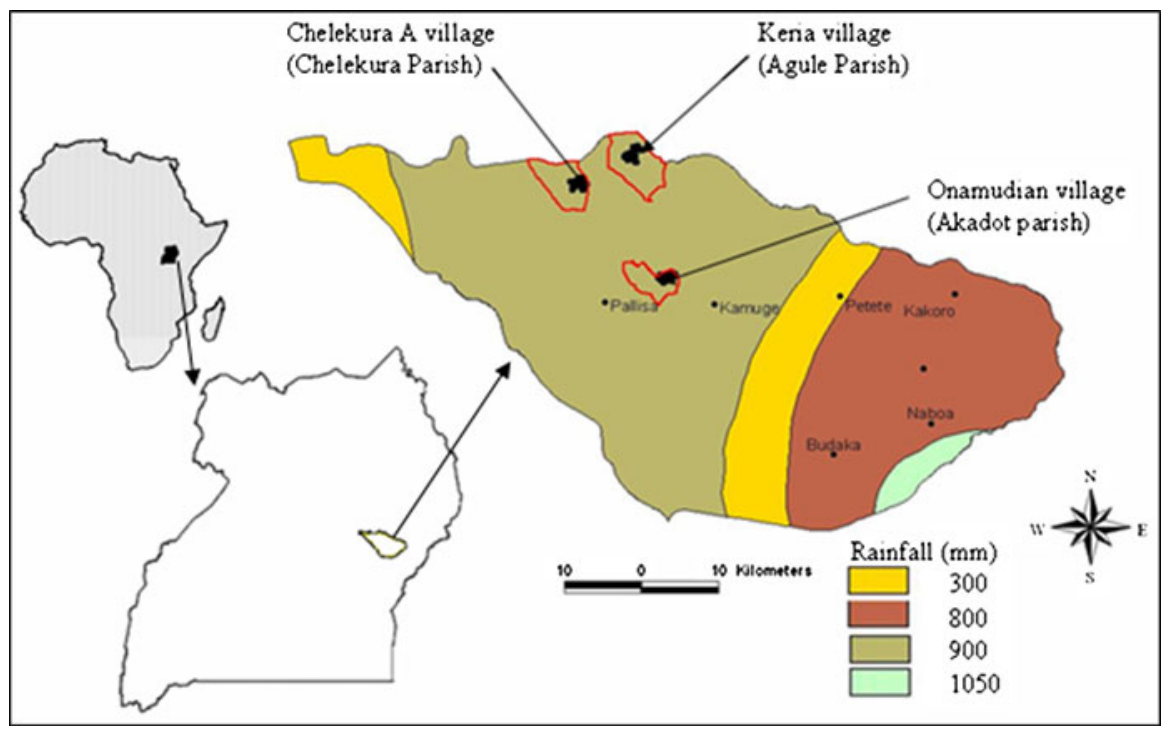

Fig. 1 Location of study sites and rainfall distribution in Pallisa district, Uganda 
crops dominate the upland and midland cropping during the rainy seasons, with free grazing of livestock after crop harvest and in the dry seasons. Valleys, which in earlier years were gazetted as communal grazing lands, are now predominantly used for rice cultivation and only support grazing to a limited extent after harvests. Where wetlands exist, they are used for fishing but may also be areas for collecting thatch grass, and papyrus for craft making.

Site selection

This study was embedded within an ongoing research project on integrated nutrient management using a 'farmer field schools' approach called 'Integrated nutrient management to attain sustainable productivity increases in East African farming systems' (INMASP). At the initiation of the INMASP project in 2002, a multistage approach was used to select pilot sites. The two sub-Counties of Agule and Pallisa were selected because of differences in population densities and soil productivity status. Agule sub-County has lower population density and soil fertility whilst Pallisa has medium population density and moderate soil fertility status (Ssali et al. 2002). The project operated in one village in each of the three parishes, i.e. Agule and Chelekura in Agule sub-County, and Akadot parish in Pallisa sub-County (Fig. 1). Detailed results on participatory diagnosis of constraints and opportunities for soil productivity improvement in these villages are summarised elsewhere (Ebanyat et al. 2003).

\section{Data collection methods}

\section{Land use cover analysis}

Land use cover analysis was done in only the two parishes of Chelekura $\left(1^{\circ} 24^{\prime} \mathrm{N}\right.$; $\left.33^{\circ} 30^{\prime} \mathrm{E}\right)$ and Akadot $\left(1^{\circ} 11^{\prime} \mathrm{N} ; 33^{\circ} 43^{\prime} \mathrm{E}\right)$. Black and white aerial photographs (1:50,000) obtained from the Department of Surveys and Mapping, Entebbe, Uganda were analysed from 1960 and Landsat images from 1973 (Multi-Spectral Scanner), 1986 (Multi Scanner) and 2001 (Enhanced Thematic Mapper), all taken between the period December and February (a period when rice fields are prepared and cotton harvesting is done). Controlled photo mosaics were constructed. The central portion of the air photos were cut out and aligned with adjacent air photos to correct for aircraft height and tilt variations. The controlled mosaics of each parish were then further oriented by matching features with survey control points for the area. Eight control points were used to georeference the constructed controlled photo mosaics and these were analysed under stereoscope, and land uses classified according to National Biomass Survey (MLWE 2002). Satellite images were classified using both unsupervised and supervised classification in Integrated Land and Water Information System (ILWIS) version 3.3. Broad land use/cover classes used in the study included forest, cultivated land, swamps, bushland, grassland, water bodies and rice cultivation-introduced as a new land use class. Preliminary maps produced after analogue and digital image interpretations were validated with 
existing land cover maps of the area (such as the GLC2000 and the Africover maps), with ground observations and through historical reconstruction. Four key informants were identified in each village and were interviewed about land use classes that existed in some locations and change that occurred over time. Information obtained was used to produce land use cover maps of the two parishes of 1960, 1973, 1986 and 2001 .

\section{Literature review}

To understand the factors that have caused land use change and to confirm farmer's perceptions, a literature review was conducted. Data at district scale on changes in human and livestock populations, acreages for finger millet and cotton were collected and used for inference since disaggregated data at parish scale were lacking. The review also included records at national research institutions, government ministries and departments and private sector organisations to identify the national policies that were implemented during the period of analysis. Population data for the district and study parishes (Fig. 2) were computed on the basis of the population growth rates between census years available with the Uganda National Bureau of Statistics. The southern Mali cotton-cereal system was used as a case study to evaluate the impacts of political stability and institutions. Literature was reviewed on production trends, soil fertility status, supportive institutions and the political status for same period, 1960-2001 considered for the Pallisa system.

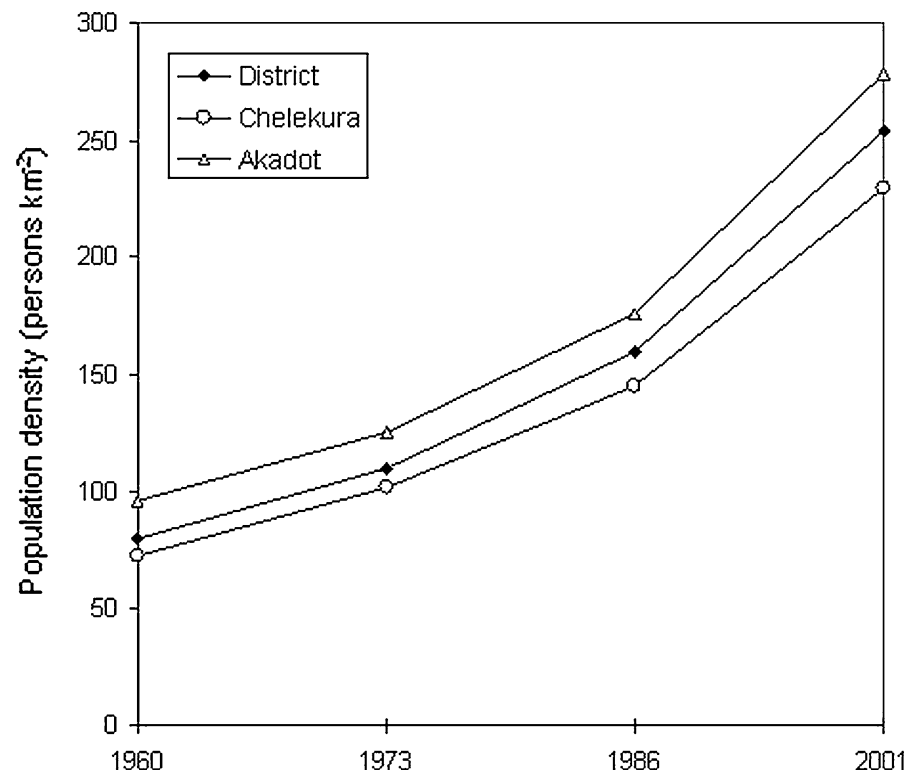

Fig. 2 Population densities of Pallisa district and study parishes from 1960 to 2001 
Household surveys

Two household surveys were conducted. The first one in March 2002 included 89 farm households participating in the INMASP project. The objective was to obtain perceptions on soil productivity trends and current soil fertility status and the driving factors, and soil fertility management practices used and related challenges. The second was a rapid survey conducted in April 2005 that included 90 farms (rapid survey farms-RSF) which included 60 none participating and 30 participating farm households (CSF) in the INMASP project. Knowing, however, that the farm households participating in the project were self selected on the basis of interest (Braun et al. 2000), data collected during this survey were used to ascertain if all the farm types in the community were represented. Data from the RSFs were collected following typical questions described in Tittonell et al. (2005) to obtain information about resource endowments and livelihood strategies of the farm households to enable construction of functional farm typologies (Tittonell 2007).

Nutrient flows and soil chemical analysis

Data were collected using questionnaires in the NUTMON tool box (Vlaming et al. 2001) from the 30 case study farms in March 2003. Nutrient flows into and out of the farms and distribution within the farms was captured during a one-time recall survey for the two seasons of the previous year 2002 through resource flow mapping. Inflows were mainly through nutrient inputs and outflows in the form of farm products. To quantify the soil nutrient stocks, soil samples were taken from 0 to $30 \mathrm{~cm}$ depth from fields on farm section units (major local soil units) identified with farmers on respective farms for analysis of total $\mathrm{N}, \mathrm{P}$ and $\mathrm{K}$, particle size distribution and bulk density following standard methods for tropical soils (Anderson and Ingram 1993).

\section{Data analysis}

Relationships between land use and cover data and population density were explored using correlation analysis and the strengths of the relationships inferred from the square of the correlation coefficients. Differences in respondent's perceptions between sites were tested using Pearson Chi square. To generate farm typologies, farm data was subjected to (di) similarity agglomerative cluster analysis using the cosine similarity index because of sensitivity to both quantitative and qualitative data (Jongman et al. 1995). Nutrient balances were computed using the NUTMON software version 3.5 from the inflow and outflow data at both farm and crop level and significances tested using a $T$ test for farm balances and ANOVA for crop-level balances. Regression analyses were performed to identify farm household characteristics influencing nutrient balances and nutrient balance to stock ratios (NBSR) of the major nutrients at both farm and crop level. NBSR were computed as ratios of farm balances to nutrient stocks for all fields in a given farm and at the crop-level, nutrient balances to nutrient stocks only for fields where crops were 
grown. Only variables that were not significantly correlated were used as explanatory variables. All statistical analysis was performed using SPSS version 12.

\section{Results and discussion}

Land use change and associated drivers

The major land uses identified in the studied parishes in Pallisa district were forest, cultivated lands grouped with homesteads, bush lands, grasslands, papyrus swamps and rice cultivation. These land uses have undergone drastic changes over the 41 years of analysis in both parishes (Fig. 3-Chelekura and Fig. 4-Akadot). Their proportionate spatial coverage is summarised in Table 1. In 1960, cultivated land and homesteads occupied 24 and $53 \%$ of the total land area in Chelekura and Akadot parishes, respectively, indicating comparatively more intensive land use in the latter parish. Land cultivated declined in both parishes in 1973 but again increased in 1986 to areas comparable but not surpassing those of 1960. By 2001, land brought to cultivation increased by 90 and 48\%, respectively, in Chelekura and Akadot compared with 1960. The increases in cultivated lands were, however, paralleled by declines and eventual disappearance of some land uses. After 1986, grasslands, which were mainly grazing lands closer to swamps, and bushlands, declined very rapidly leaving none by 2001 in both parishes. The swamps also declined but at a much faster rate in Akadot than in Chelekura parish and by 2001 swamps covered only $6 \%$ of total land area in Chelekura and none was remaining in Akadot parish.

In 1960, more land was cultivated in Akadot than in Chelekura parish because cotton growing was more intense in this parish than in Chelekura which mainly had livestock and more grazing/grasslands and bushlands (Table 1). According to key informants Chelekura was comparatively less inhabited which is supported by population density estimates of 80 persons $\mathrm{km}^{-2}$ (Fig. 2). Akadot parish had two cotton ginneries at Akadot and Kaboloi and most farmers grew cotton which they easily transported and sold at the ginneries. At that time cotton was promoted as a major crop for households to raise cash for paying poll tax making men more involved in its production.

The increase in cultivated land and disappearance of other land uses over the period of analysis is associated with population growth. Population density negatively correlated with all land uses except for cultivated land $(r=0.70)$ and rice cultivation $(r=0.78)$ that were positive and significant (Table 2). From these results, population explains only 49 and $60 \%$ of increases in cultivated land and rice cultivation. Cultivated land was significantly negatively correlated with grasslands $(r=-0.84)$ and bushlands $(r=-0.64)$, and so was bushlands with rice $(r=$ $-0.71)$ implying that they were over time converted to cultivated lands and rice cultivation, respectively. There have been immigrations to the area in search of land during the 41 years of analysis (although exact statistics were not available in the district) due to insecurity in the north eastern region but in particular from the mid 1980s. Other factors, however, modify the effects of population growth in 
(a) 1960

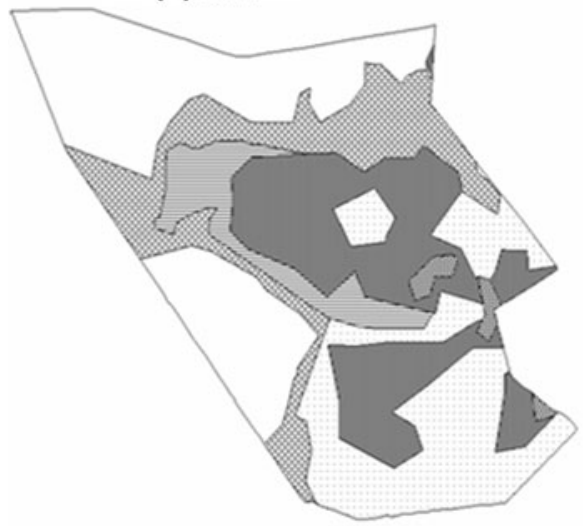

(c) 1986
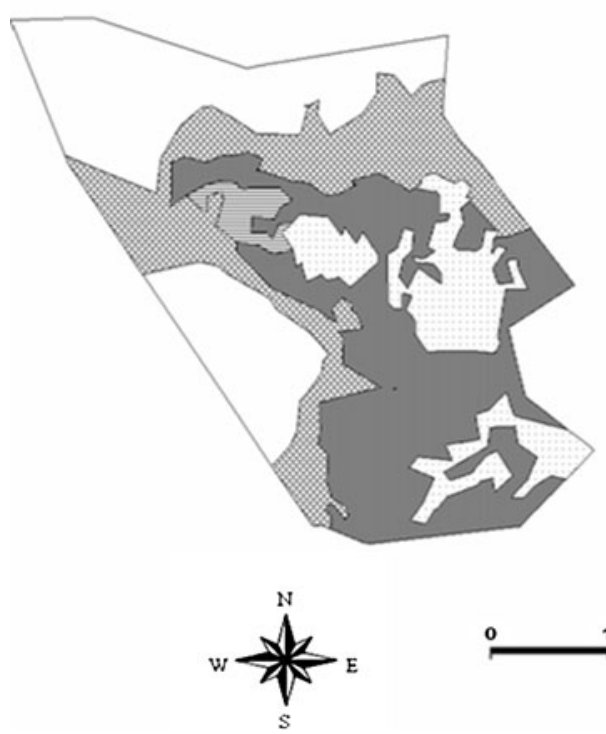

(b) 1973

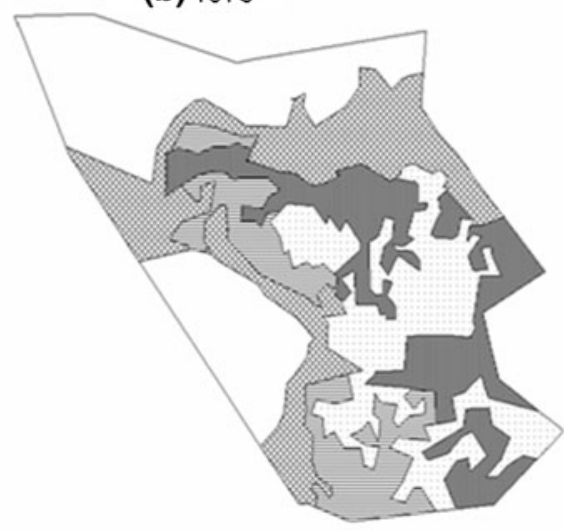

(d) 2001
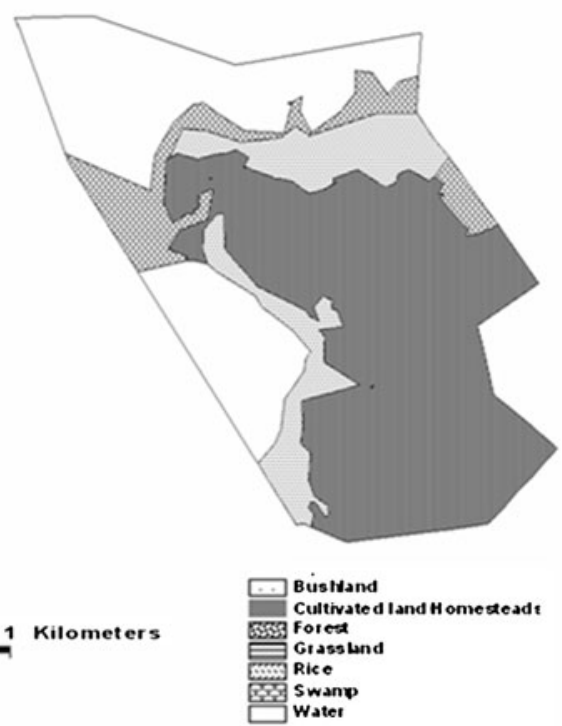

Fig. 3 Land use change in Chelekura parish, Pallisa district from 1960 to 2001

explaining the temporal and spatial changes in land use. We strongly argue that the underlying effects of national political instability and changing economic policies that rippled through the country had a share in this.

The country was affected by political instability and economic decline for half of the period of analysis (Fig. 5). The period 1960-1970 was characterised by agriculture-led economic growth (GOU 1965) and political stability. The post independence government continued pursuing colonial economic development policies which prioritised export of cotton and coffee for foreign earnings. Implementation of colonial policies continued although in a rather less punitive way 
(a) 1960

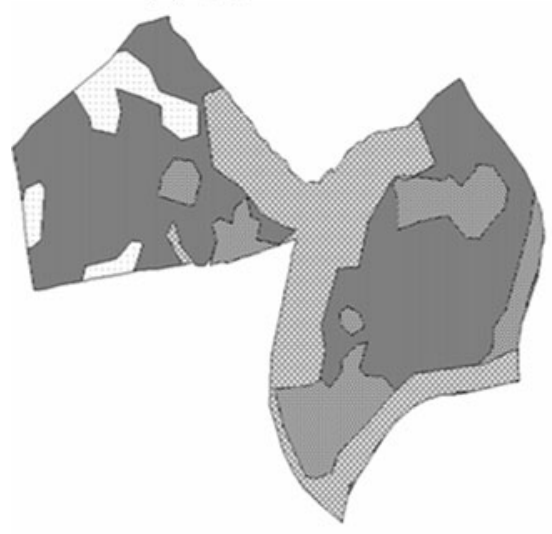

(c) 1986

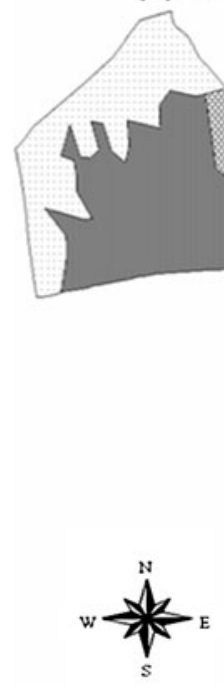

(b) 1973

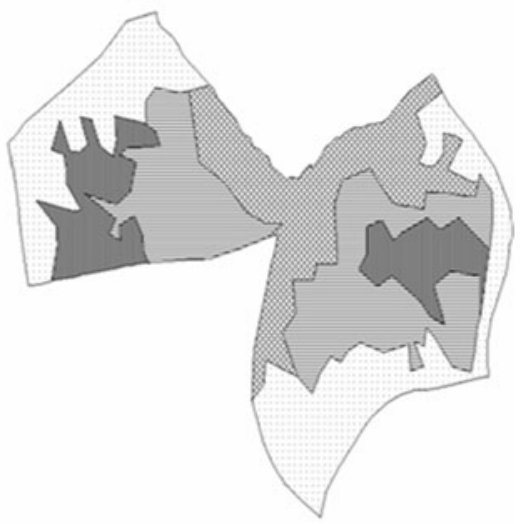

(d) 2001
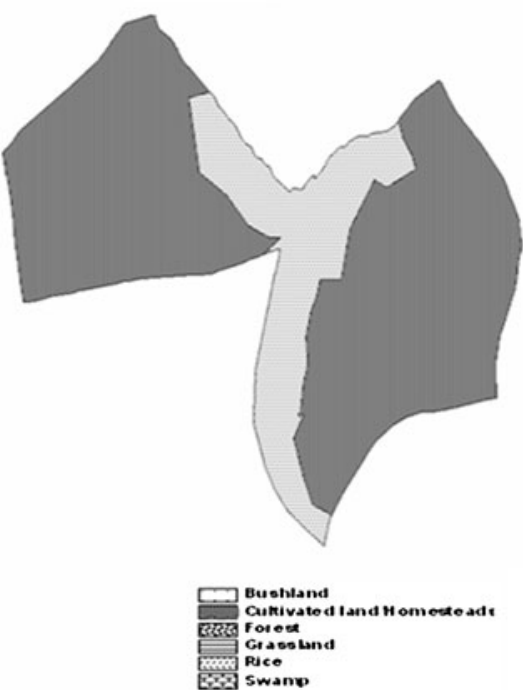

Fig. 4 Land use change in Akadot Parish, Pallisa district from 1960 to 2001

than during the colonial administration. Model farmers were promoted and agricultural implements and fertilisers were subsidised. However, large scale farmers with plantation estates (sugarcane and tea) rather than subsistence farmers benefited from the subsidies even though export growth came from cotton and coffee produced by subsistence farmers. Cotton and finger millet were popular crops respectively grown by 85 and $66 \%$ of farmers for cash and subsistence in the Pallisa region (MAC 1966). At this time, there was a strong crop-livestock interaction in the system. Ox-ploughing, a practice which was introduced in the area at around the same time with cotton in 1910 (Mahadevan and Parsons 1970), enabled opening of large acreages and preparation of fine seed beds. For finger millet in particular, 
Table 1 Land use/cover and changes in Chelekura and Akadot Parishes, Pallisa district, eastern Uganda from 1960 to 2001

\begin{tabular}{|c|c|c|c|c|c|c|c|c|c|c|c|}
\hline \multirow[t]{3}{*}{ Parish/land use } & \multicolumn{8}{|c|}{ Cover } & \multicolumn{3}{|c|}{ Changes $^{\mathrm{a}}$} \\
\hline & \multicolumn{2}{|l|}{1960} & \multicolumn{2}{|l|}{1973} & \multicolumn{2}{|l|}{1986} & \multicolumn{2}{|l|}{2001} & \multirow{2}{*}{$\begin{array}{l}1973 \\
\text { (ha) }\end{array}$} & \multirow{2}{*}{$\begin{array}{l}1986 \\
\text { (ha) }\end{array}$} & \multirow{2}{*}{$\begin{array}{l}2001 \\
\text { (ha) }\end{array}$} \\
\hline & (ha) & $(\%)$ & (ha) & $(\%)$ & (ha) & $(\%)$ & (ha) & $(\%)$ & & & \\
\hline \multicolumn{12}{|l|}{ Chelekura } \\
\hline Cultivated land/homesteads & 592 & 24 & 441 & 18 & 518 & 21 & 1127 & 46 & -151 & -74 & 535 \\
\hline Forest & 30 & 1 & 0 & 0 & 0 & 0 & 0 & 0 & -30 & -30 & -30 \\
\hline Grasslands/trees & 324 & 13 & 231 & 9 & 231 & 9 & 0 & 0 & -93 & -93 & -324 \\
\hline Bush lands & 586 & 24 & 455 & 18 & 417 & 17 & 0 & 0 & -131 & -169 & -586 \\
\hline Papyrus swamps & 202 & 8 & 606 & 25 & 567 & 23 & 148 & 6 & 404 & 365 & -54 \\
\hline Rice cultivation & 0 & 0 & 0 & 0 & 0 & 0 & 458 & 19 & 0 & 0 & 458 \\
\hline Water & 730 & 30 & 730 & 30 & 730 & 30 & 730 & 30 & 0 & 0 & 0 \\
\hline Total & 2463 & 100 & 2463 & 100 & 2463 & 100 & 2463 & 100 & 0 & 0 & 0 \\
\hline \multicolumn{12}{|l|}{ Akadot } \\
\hline Cultivated land/homesteads & 627 & 53 & 177 & 15 & 606 & 51 & 926 & 78 & -450 & -21 & 298 \\
\hline Forest & 195 & 16 & 0 & 0 & 0 & 0 & 0 & 0 & -195 & -195 & -195 \\
\hline Grassland/trees & 0 & 0 & 480 & 40 & 195 & 16 & 0 & 0 & 480 & 195 & 0 \\
\hline Bush lands & 69 & 6 & 288 & 24 & 319 & 27 & 0 & 0 & 219 & 250 & -69 \\
\hline Papyrus swamps & 301 & 25 & 246 & 21 & 71 & 6 & 0 & 0 & -55 & -229 & -301 \\
\hline Rice cultivation & 0 & 0 & 0 & 0 & 0 & 0 & 266 & 22 & 0 & 0 & 266 \\
\hline Total & 1192 & 100 & 1192 & 100 & 1192 & 100 & 1192 & 100 & 0 & 0 & 0 \\
\hline
\end{tabular}

a Base year for computation is 1960

Table 2 Pearson's correlation coefficients for land use types and population density in Pallisa District

Cultivated land/ Forest Grasslands bushlands Papyrus Rice Pop.

homesteads swamps density

\begin{tabular}{|c|c|c|c|c|c|c|c|}
\hline $\begin{array}{l}\text { Cultivated land/ } \\
\text { homesteads }\end{array}$ & 1 & & & & & & \\
\hline Forest & -0.07 & 1 & & & & & \\
\hline Grassland & $-0.84 *$ & -0.38 & 1 & & & & \\
\hline Bushlands & $-0.64 *$ & -0.27 & $0.75^{*}$ & 1 & & & \\
\hline Papyrus swamp & -0.49 & 0.41 & 0.20 & 0.51 & 1 & & \\
\hline Rice & $0.87 * *$ & -0.24 & -0.62 & $-0.71 *$ & -0.47 & 1 & \\
\hline Pop. density & $0.70^{*}$ & -0.40 & -0.56 & $-0.71^{*}$ & -0.51 & $0.78 *$ & 1 \\
\hline
\end{tabular}

$* P<0.05 ; * * P<0.01$

labour for the tedious weeding and harvesting was communally organised to help one another ('Ebole'), and rewarded with a meal and local brew, 'ajon', at the end of the season.

The decline in cultivated land in 1973 is associated with a change in the political governance and economic policies of the country following the take over by Idi 


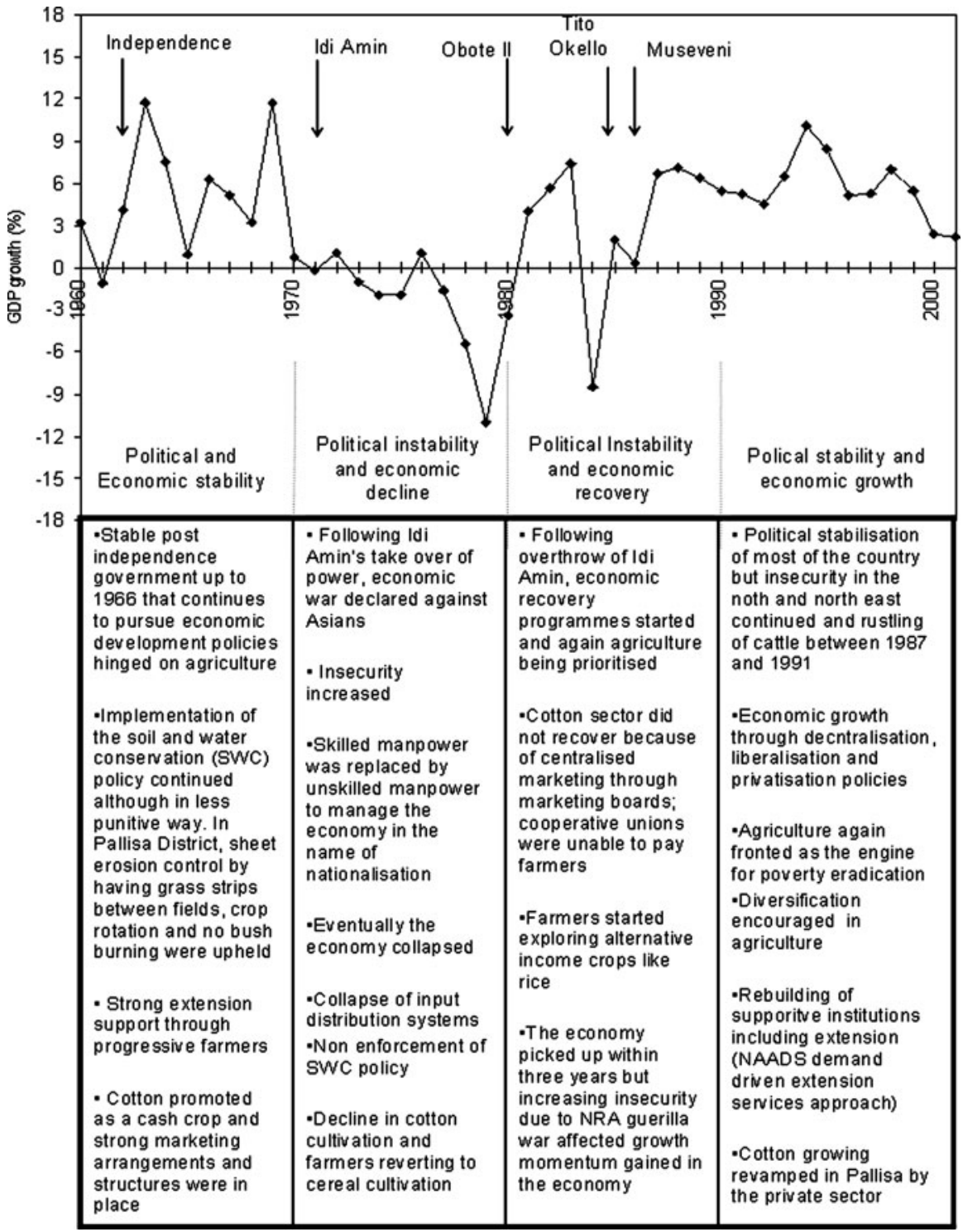

Fig. 5 Uganda's political timelines and economic performance and their impacts on land use from 1960 to 2001. A = period of political and economic stability; B = Period of political instability and economic decline; $\mathrm{C}=$ Period of political instability and economic recovery; $\mathrm{D}=$ Period of political stability and economic growth (Sources: GoU 1965, 1967, 1972, 1996; MFPED 1990; UBOS 1999, 2004; Kamugisha 1993; Tukahirwa 1996; Walaga et al. 2000)

Amin in 1971. Economic war was declared and the Asian community that dominated the business and trade sector including cotton marketing were expelled. This demoralised smallholders from cultivation of the crop and indeed in Akadot and Chelekura parishes cultivated area declined by 38 and $6 \%$, respectively. The 
political instability in the 1970s until the mid 1980s impacted on all the sectors of the economy including agriculture culminating in a complete collapse of cotton marketing in the early 1980s. Farmers had to explore alternative cash-income crops. According to key informants from both parishes of Chelekura and Akadot, farmers soon started to grow rice on grasslands (grazing areas) on the flanks of the swamps from 1982 onwards but initially left the seasonal swamps to provide pastures for the dry season grazing. The Obote II government (1980-1985) adopted some economic recovery programmes but the escalating guerrilla war continued to increase insecurity and weakened institutions. Policies, including land management policies could not be enforced (Tukahirwa 1996) making it difficult to restrain encroachment of wetlands by rice cultivation. Farmers diversified to growing other crops for both domestic consumption and cash, i.e. grain legumes and cassava (Kidoido et al. 2002) leading to expansion of cultivated areas again in the uplands.

Cattle population in Pallisa District drastically dropped from over 123,000 in 1985 to only 20,000 in 1991 (MAAIF 1993) following insecurity and the extensive cattle rustling in the region. Further expansion of rice cultivation into the valley bottoms became much easier because competition from grazing no longer existed. From 1987 the economic liberalisation policies and export drive further encouraged crop diversification. Cultivation soon started in the dry seasons (November-February) where valleys accumulated water leading to double cropping. In effect, all the swamps and grazing lands in Akadot parish were brought into cultivation and $94 \%$ in Chelekura parish by 2001 (Table 1). These examples illustrate that farmers are flexible and search for farming strategies that enable them to cope with externally imposed constraints arising from political and economic forces (Berry 1993). Expanding cultivated land and intensifying use of valley bottoms seemed to be less driven by population increase in this case than searching for an alternative income enterprise, as has been summarised from other literature by Crowley and Carter (2000).

The above political trends and their effects on institutional arrangements contrast with the Malian system which comparatively experienced more political stability throughout the period of analysis. The Mali government prioritised the cotton sector in national development and initiated the establishment of Compagnie Malienne pour le Developpment des Fibres Textiles (CMDT), which has supported the cotton sector since 1960. CMDT co-ordinated all production and marketing arrangements. It stabilised input and output markets for cotton, maintained partnerships with supportive institutions in cotton production like research and extension and empowered local farmer organisations like Syndicat des Productuers de Cotton et Vivries (SYCOV) and village producer associations (Bingen 1998; Tefft 2004). Because of assured markets from cotton sales, farmers have been able to increase livestock numbers, oxen and carts. Thus manure production increased, opening of larger acreages has been possible through ox-ploughing and transportation of manure to the fields became easier as the oxen for traction and ox carts are available. Input credit availability ensures timely availability of seed, pesticides and fertiliser. There are also well-organised family labour structures provided by extended family units around specific production activities that take care of the farm operations in a timely manner. In consequence, productivity of the farming system improved with time because coordination ensured good crop husbandry and 
marketing (Tefft 2004). These institutional arrangements that were created through good national policies and a relatively stable political environment ensured the improvement and sustaining of cotton production in Mali. This provides an example of how politics and economic stability, and institutional support to market-oriented crop production are important in the quest to improve livelihood security and productivity of smallholder farming systems in Africa. We can therefore clearly attribute political instability, lack of supportive input-output markets and land management services, break down in communal labour arrangements and loss of cattle, interacting with population growth, drove land use changes in the Teso farming system. These findings reiterate that land use change in tropical systems are gradual and result from population growth interactions with specific prevailing socio- economic factors rather than population alone (Lambin et al. 2001; Geist and Lambin 2002; Keys and McConnell 2005).

Farming systems and sustainability

\section{Farm types}

Data on household characteristics was used to generate farm typologies and their allocation of land to various land uses. Four major farm typologies; larger farms (LF), medium farms (MF), small farms with cattle (SF1) and small farms without cattle (SF2) were constructed using the rapid survey data on wealth indicators as land area and cattle ownership combined with indicators of livelihood strategies, labour sale/hire, food security status and income sources (Table 3). These criteria tallied with those prioritised by farmers (land area, livestock, food security and type of housing). The combination of wealth and livelihood indicators improved the classification above and using only land and livestock as done by Awa et al. (1999) for the same Teso farming system.

The respective proportions of the LF, MF, SF1 and SF2 in the RSF were 11, 30, 39 and $20 \%$ but note that LF and SF2 were over represented in the CSF (Table 4). Farms differed in resource endowments. The LFs on average owned 5 ha of land, 9 cattle and 4 goats. The MFs had on average 2 ha of land, 3 cattle and 1 goat. The SF1s types had at least 1 ha of land, owned at least 1 cattle and 1 goat. The SF2s had less than 1 ha of land, no cattle, at least one goat and were the most food insecure amongst the four types because of limited production resources. Dependency on off farm income was another important livelihood strategy for the farmers in Pallisa. Fifty-eight per cent of total farm income of LF types was from off-farm activities, especially small scale businesses, and produced some specific crops like maize and rice for sale. These farm types had a land to labour ratio of 2.1. The MF types had some off-farm employment in civil service but supplement their income by growing crops for sale in particular cotton. Off-farm income constituted $42 \%$ of their total income and the land to labour ratio was 1.2. For the SF1, incomes were generated from sale of both food and cash crops. The proportion of total incomes from offfarm on these farms is $21 \%$ and the land to labour ratio was 1 . They grow cassava, rice and grain legumes like groundnut and cowpea. For the SF2s off-farm income is less important and constitutes $14 \%$ of total income but the households mainly 
Table 3 Wealth indicators and characteristics of the different resource groups in Pallisa district, Uganda

\begin{tabular}{|c|c|c|c|c|}
\hline \multirow{2}{*}{$\begin{array}{l}\text { Wealth } \\
\text { indicator }\end{array}$} & \multicolumn{4}{|l|}{ Resource category $^{\mathrm{a}}$} \\
\hline & LF & MF & SF1 & SF2 \\
\hline Farm size & Have about 5 ha & Have about 1.6 ha & Approximately 1 ha & Less than 1 ha \\
\hline \multirow[t]{2}{*}{ Livestock } & $\begin{array}{l}\text { Have about } 9 \text { cattle } \\
\text { with at least one } \\
\text { pair of oxen }\end{array}$ & $\begin{array}{l}\text { Have about } 3 \text { cattle with } \\
\text { either one ox or a pair of } \\
\text { oxen }\end{array}$ & $\begin{array}{l}\text { At least have } 1 \text { ox to } \\
\text { team with another } \\
\text { farmer for draught } \\
\text { power }\end{array}$ & $\begin{array}{l}\text { Do not have } \\
\text { cattle, but at } \\
\text { least have } \\
\text { goats }\end{array}$ \\
\hline & Have about 4 goats & Have about 4 goats & $\begin{array}{l}\text { May have about } 3 \\
\text { goats }\end{array}$ & \\
\hline $\begin{array}{l}\text { Hire/sale of } \\
\text { labour }\end{array}$ & $\begin{array}{l}\text { Hire labour for } \\
\text { livestock and } \\
\text { casual labour for } \\
\text { cropping activities }\end{array}$ & $\begin{array}{l}\text { Hire labour for cropping } \\
\text { activities. Also hire out } \\
\text { labour particularly oxen } \\
\text { for ploughing }\end{array}$ & $\begin{array}{l}\text { Sell and hire labour } \\
\text { for cropping }\end{array}$ & Sell labour \\
\hline $\begin{array}{l}\text { Farm } \\
\text { implements }\end{array}$ & $\begin{array}{l}\text { Own ox plough, hoes } \\
\text { and wheel barrows }\end{array}$ & Own ox plough, hand hoes & $\begin{array}{l}\text { May own an ox } \\
\text { plough and hand } \\
\text { hoes }\end{array}$ & $\begin{array}{l}\text { Own only } \\
\text { hand hoes }\end{array}$ \\
\hline $\begin{array}{l}\text { Production } \\
\text { orientation }\end{array}$ & $\begin{array}{l}\text { Grow some root and } \\
\text { grain crops } \\
\text { specifically for sale }\end{array}$ & $\begin{array}{l}\text { Produce mainly for home } \\
\text { consumption and some } \\
\text { crops for sale }\end{array}$ & $\begin{array}{l}\text { Produce for home } \\
\text { consumption and } \\
\text { can sell any crop } \\
\text { for income }\end{array}$ & $\begin{array}{l}\text { Produce for } \\
\text { basically } \\
\text { home } \\
\text { consumption }\end{array}$ \\
\hline $\begin{array}{l}\text { Income } \\
\text { sources }\end{array}$ & $\begin{array}{l}\text { Have small scale } \\
\text { businesses and } \\
\text { remittances from } \\
\text { working relatives }\end{array}$ & $\begin{array}{l}\text { Rely on crop sales and } \\
\text { salary as civil servants } \\
\text { (teachers) }\end{array}$ & $\begin{array}{l}\text { Sale of crop } \\
\text { products and local } \\
\text { brew }\end{array}$ & $\begin{array}{l}\text { Sale of labour } \\
\text { and a little } \\
\text { of crop } \\
\text { products }\end{array}$ \\
\hline $\begin{array}{l}\text { Food } \\
\text { security }\end{array}$ & $\begin{array}{l}\text { Buy food for periods } \\
\text { less than } 1 \text { month } \\
\text { in a year }\end{array}$ & $\begin{array}{l}\text { Buy food for periods } \\
\text { of } 1-3 \text { months }\end{array}$ & $\begin{array}{l}\text { Buy food for } \\
3-5 \text { months } \\
\text { in a year }\end{array}$ & $\begin{array}{l}\text { Buy food for } \\
\text { more than } \\
5 \text { months in } \\
\text { a year }\end{array}$ \\
\hline
\end{tabular}

${ }^{\text {a }} L F$ Larger farms, $M F$ Medium farms, SF1 Small farms with cattle, SF2 Small farms without cattle

survive on sale of own labour in the community. This category was land limited and had a land to labour ratio of 0.95 .

\section{Farm-level land use}

Land allocation to crops was used to explore change in the cropping systems. The land allocation to crops varied between farm types (Fig. 6) and reflects differences in farmer's production objectives like for domestic consumption or cash. Cassava however takes the second highest share of land area after fallow in each farm type. As there were no significant differences between farm types between villages. We therefore used the average land allocation fractions per farm type (Fig. 6) and household numbers in each parish; 914 for Chelekura and 804 for Akadot (UBOS 2005) to estimate the crop coverage of the cultivated land in each parish. The estimates have an error of $\pm 18 \%$. Crop shares of land between the parishes significantly differed $(P<0.05)$ but there were notable variations in the proportions of land allocated to each crop within each site (Fig. 7). Cassava occupied more that 


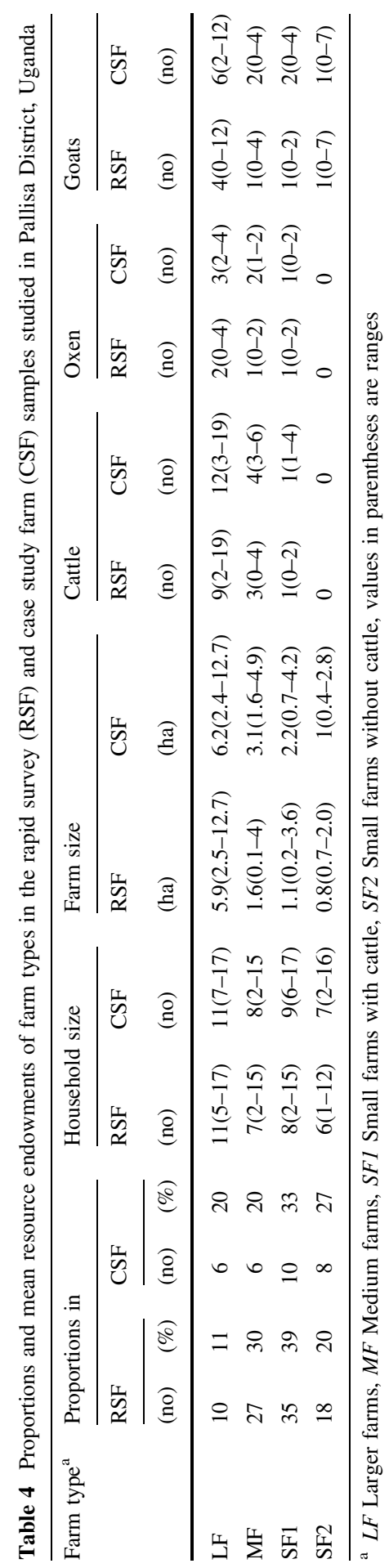




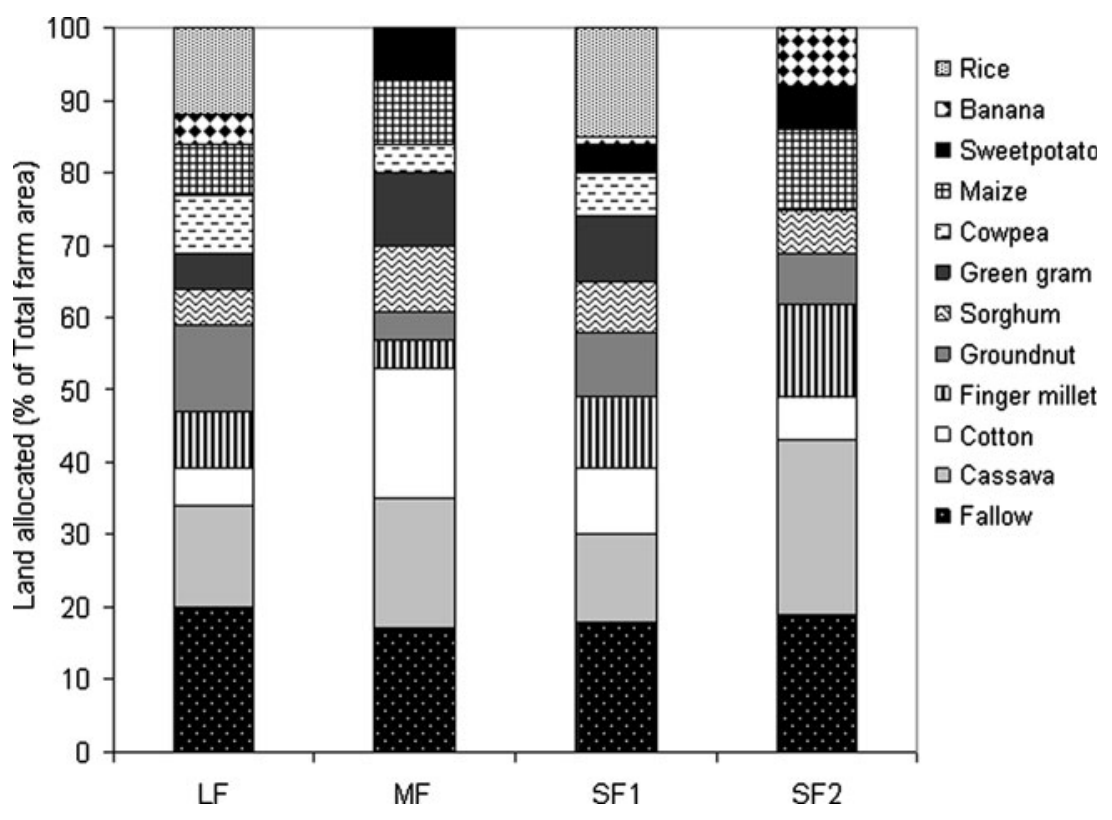

Fig. 6 Percentage Land allocation per farm type in Pallisa district (2 seasons). $L F$ larger farms, $M F$ medium farms, SF1 small farms with cattle, SF2 small farms without cattle

250 ha of cultivated land in each of the parishes overtaking the earlier important crops, cotton and finger millet in importance in the region.

In the 1960s farmers owned on average 2 ha of land (Carr 1982) with over $75 \%$ of it allocated to cotton and finger millet production. Cassava was then a less important crop in the farming system (MAC 1963). Four decades later with diminishing average farm sizes, cassava takes the leading share of $20 \%$ reflecting a change in the cropping system compared with the 1960s. District-level estimates also support changes in cropping although accuracy of land area estimates may be questionable. In 1960, cotton covered approximately 50,000 ha and finger millet, 60,000 ha-respectively 25 and 30\% of the total land area in the district (McMaster 1962). By 1991, the areas cultivated to both crops drastically reduced with millet occupying only $5 \%$ of the land area and cotton less than $2 \%$ (GoU 1976; MAAIF 1993). The area cultivated to cotton increased to $9 \%$ and that of millet remained at 5\% in 2001 (UIA 2002; MAAIF 2003). The change in the cropping systems occurred because of economic pursuits by farmers to improve incomes but also due to biophysical constraints especially declining soil fertility. Cassava is an important food security crop as well as a tradable food crop and is well-adapted to poor soil fertility (Howeler 2002), which could explain why it has become a dominant crop over time. Diminishing land holdings and collapse of communal labour arrangements for weeding might explain declines in land allocation to finger millet, a crop high in labour demand, whereas the collapse of markets could explain decline of cotton production in the district. This agrees with Crowley and Carter (2000) who 


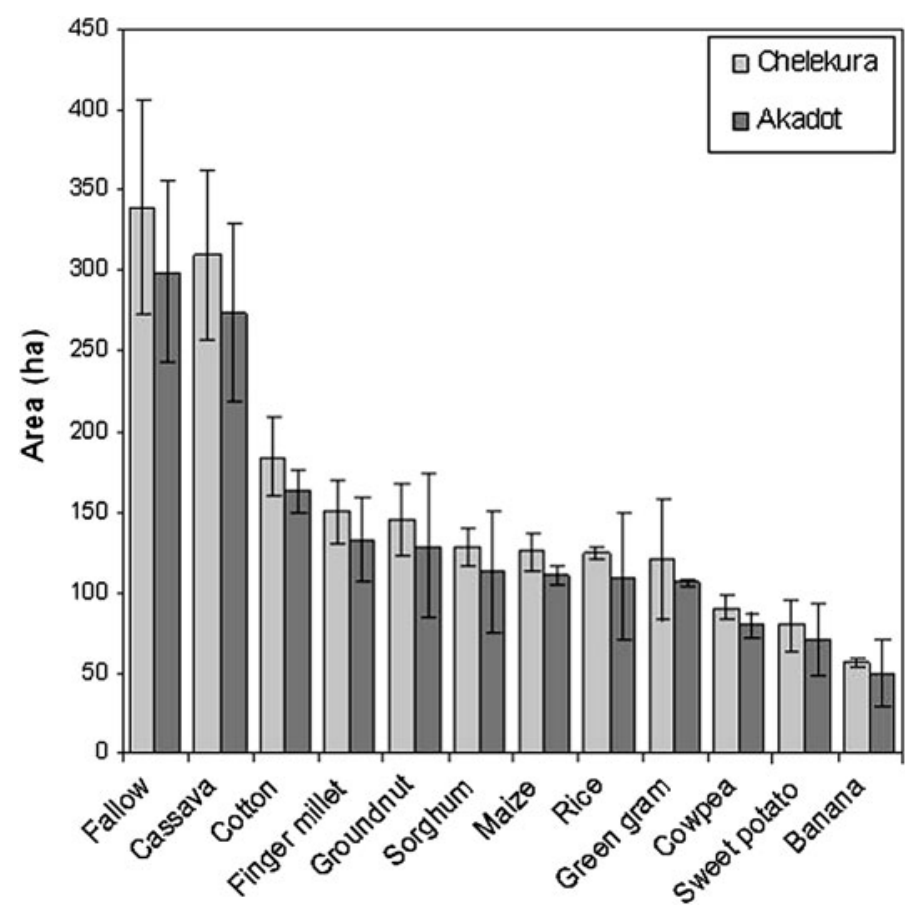

Fig. 7 Average land area allocated to different crops and standard deviations in Chelekura and Akadot parishes

report that farmer's responses to constraints such as lack of inputs and market failures feed back to the biophysical environment, especially to soil fertility. The emergence of rice was purely an alternative source of income and without institutions to implement land management policies, swamps have been encroached.

\section{Nutrient flows and balances}

Farm-level nutrient flows were variable and differed between farm types. Only grazing (IN2b) and manure losses (OUT2b) significantly differed between farm types at $P<0.05$ (Table 5). The contribution of inflow of major nutrients on the farms due to grazing amounted to 84,80 and $94 \%$ of the total farm inflows for $\mathrm{N}, \mathrm{P}$ and $\mathrm{K}$, respectively, for LF, 67, 50 and $86 \%$ for MF, 62, 50 and $86 \%$ for SF1 and 23, 5 and $40 \%$ for SF2. The variation in contributions correspond with the cattle endowments of the farms (see Table 4). Contributions of other inflows that included organic residues (IN2a), atmospheric deposition (IN3) and biological nitrogen fixation for N (IN4) were small, whilst no external fertilisers (IN1) were used on any of the farms. Manure losses (OUT2b) were significantly different between farms because of cattle numbers. It, respectively, accounted for 46, 67, 81\%; 32, 50, 69\%; $27,50,69 \%$ and 3, 5, 20\% of the total losses of N, P and K on LF, MF, SF1 and SF2 farms, respectively. Although not significantly different between farms, leaching 
(OUT3) was generally a more important pathway for $\mathrm{N}$ loss than via manure on all the farms.

Nutrient balances significantly differed $(P<0.01)$ for $\mathrm{N}$ and $(P<0.05)$ for $\mathrm{P}$ between farm types. However, $T$ tests showed only SF1 $\left(-9 \mathrm{~kg} \mathrm{~N} \mathrm{ha}^{-1}\right)$ and SF2 $\left(-16 \mathrm{~kg} \mathrm{~N} \mathrm{ha}^{-1} ;-1 \mathrm{~kg} \mathrm{P} \mathrm{ha}^{-1}\right)$ farm types to have balances significantly lower than zero (Table 5) implying higher depletion rates on these farms. The reason may be due to low cattle numbers and no cattle, respectively, on these farm types. Total balances across the farms show deficits for $\mathrm{N}\left(-16 \mathrm{~kg} \mathrm{ha}^{-1}\right)$ and surplus for $\mathrm{K}$ $\left(+23 \mathrm{~kg} \mathrm{ha}^{-1}\right)$, but are balanced for $\mathrm{P}\left(0 \mathrm{~kg} \mathrm{ha}^{-1}\right)$. The negative balances for $\mathrm{N}$ are attributed to high losses of manure and leaching in the sandy soils. Because $\mathrm{P}$ is immobile, losses of $\mathrm{P}$ through erosion are easily compensated through grazing inputs that bring in manures to the farms. Surplus K could be explained by high K contents in manure because grasses grazed by cattle grow on soils that are rich in $\mathrm{K}$ (Ollier and Harrop 1959). The results suggest a need for better management of manure collection and storage to minimise $\mathrm{N}$ losses for farm types that have cattle.

Nutrient balances for all crops were negative on all farm types but not significantly different between farm types (Table 6). This was contrary to the farm-

Table 5 Average flows and balances of major nutrients $\left(\mathrm{kg} \mathrm{ha}^{-1}\right)$ on farms of different resource endowments in Pallisa District, Uganda

\begin{tabular}{|c|c|c|c|c|c|c|c|c|c|c|c|c|}
\hline \multirow[t]{2}{*}{ Flows } & \multicolumn{4}{|c|}{ Nitrogen } & \multicolumn{4}{|c|}{ Phosphorus } & \multicolumn{4}{|c|}{ Potassium } \\
\hline & LF & MF & SF1 & SF2 & LF & MF & SF1 & SF2 & LF & $\mathrm{MF}$ & SF1 & SF2 \\
\hline \multicolumn{13}{|l|}{ Inflows } \\
\hline IN1 & 0 & 0 & 0 & 0 & 0 & 0 & 0 & 0 & 0 & 0 & 0 & 0 \\
\hline IN2a & 0 & 1 & 1 & 4 & 0 & 0 & 0 & 1 & 0 & 0 & 0 & 3 \\
\hline IN2b & 36 & 14 & 13 & 3 & 4 & 1 & 1 & 0.1 & 51 & 19 & 18 & 4 \\
\hline IN3 & 5 & 5 & 5 & 5 & 1 & 1 & 1 & 1 & 3 & 3 & 3 & 3 \\
\hline IN4 & 2 & 1 & 2 & 1 & 0 & 0 & 0 & 0 & 0 & 0 & 0 & 0 \\
\hline$\sum I N$ & 43 & 21 & 21 & 13 & 5 & 2 & 2 & 2 & 54 & 22 & 21 & 10 \\
\hline \multicolumn{13}{|l|}{ Outflows } \\
\hline OUT1 & 0 & -1 & -1 & -3 & 0 & 0 & 0 & -1 & 0 & 0 & -1 & -3 \\
\hline OUT2a & 0 & 0 & 0 & -1 & 0 & 0 & 0 & 0 & 0 & 0 & 0 & 0 \\
\hline OUT2b & -15 & -7 & -8 & -1 & -2 & -1 & -1 & -0.1 & -21 & -9 & -11 & -2 \\
\hline OUT3 & -12 & -9 & -13 & -15 & 0 & 0 & 0 & 0 & -2 & -2 & -1 & -1 \\
\hline OUT4 & -3 & -2 & -3 & -3 & 0 & 0 & 0 & 0 & 0 & 0 & 0 & 0 \\
\hline OUT5 & -1 & 0 & -1 & -1 & 0 & 0 & -1 & -1 & -2 & -1 & -2 & -2 \\
\hline OUT6 & -2 & -3 & -4 & -5 & -1 & -1 & -1 & -1 & -1 & -1 & -1 & -2 \\
\hline$\sum$ OUT & -33 & -22 & -30 & -29 & -3 & -2 & -3 & -3 & -26 & -13 & -16 & -10 \\
\hline Balance & $10^{\mathrm{Ns}}$ & $-1^{\mathrm{Ns}}$ & $-9 * *$ & $-16^{* * *}$ & $2^{\mathrm{Ns}}$ & $0^{\mathrm{Ns}}$ & $-1^{\mathrm{Ns}}$ & $-1 *$ & $28^{\mathrm{Ns}}$ & $9^{\mathrm{Ns}}$ & $5^{\mathrm{Ns}}$ & $0^{\mathrm{N}}$ \\
\hline
\end{tabular}

IN1 Mineral fertilisers, IN2a Organic manures, IN2 $b$ Grazing, IN3 Atmospheric deposition, IN4 Biological nitrogen fixation, OUT1 Crop products, OUT2 $a$ Crop residues, OUT2 $b$ Manure, OUT3 Leaching, OUT4 Gaseous losses, OUT5 Erosion, OUT6 Human excreta

Balance $=\sum \mathrm{IN}-\sum \mathrm{OUT}$

$* P<0.05, * * P<0.01$, Ns not significant 
Table 6 Nutrient balances for selected crops and nutrient stocks per farm type in Pallisa District, Uganda $\left(\mathrm{kg} \mathrm{ha}^{-1}\right)^{\mathrm{a}}$

\begin{tabular}{|c|c|c|c|c|c|c|c|c|c|c|c|c|}
\hline \multirow[t]{2}{*}{ Crop } & \multicolumn{4}{|c|}{ Nitrogen } & \multicolumn{4}{|c|}{ Phosphorus } & \multicolumn{4}{|c|}{ Potassium } \\
\hline & LF & $\mathrm{MF}$ & SF1 & SF2 & LF & MF & SF1 & $\mathrm{SF} 2$ & LF & $\mathrm{MF}$ & SF1 & SF2 \\
\hline Cassava & -8 & -6 & -6 & -13 & -1 & -2 & 0 & 0 & -3 & -1 & 3 & -1 \\
\hline Finger millet & -11 & -11 & -5 & -17 & -4 & -3 & -1 & 0 & -5 & -2 & 3 & -5 \\
\hline Cotton & -21 & -2 & -7 & -24 & -4 & -1 & -2 & -4 & -9 & 0 & 7 & -7 \\
\hline Groundnut & -11 & -3 & -2 & -3 & -4 & -1 & -1 & -1 & -8 & -1 & -1 & -1 \\
\hline Fallow & -2 & -2 & -3 & -3 & 1 & 0 & 0 & 3 & 4 & 1 & 1 & 2 \\
\hline Nutrient stocks & 3530 & 2380 & 4440 & 4350 & 3580 & 3270 & 3050 & 3470 & 11650 & 6640 & 7430 & 13560 \\
\hline
\end{tabular}

${ }^{a}$ Nutrient balances are weighted averages per farm type over two seasons

LF Larger farms, MF Medium farms, SF1 Small farms with cattle, SF2 Small farms without cattle

level balances which were positive for all nutrients on only the LF type farms (cf. Table 5). LF had the most negative nutrient balances at the crop level because of higher off-take in crop products and higher losses through manure and leaching. The $\mathrm{N}$ balances of crops on the SF2 farm types were highly negative probably because of leaching, i.e. $-15 \mathrm{~kg} \mathrm{~N} \mathrm{ha}^{-1}$ at the farm level, as is shown in Table 5. Cotton and finger millet extracted more $\mathrm{N}$ than other crops. Noteworthy also is that the fallows in the short term have limited soil fertility restorative capacity for only $\mathrm{P}$ and $\mathrm{K}$ which could be related to weathering processes.

The discrepancy between farm-level and crop-level balances on farms with higher cattle numbers in Pallisa can be explained by the fact that manure is accumulated within the redistribution units (kraals) but not redistributed to crop production fields. This reiterates the importance of scale in nutrient balance analysis (Haileslassie et al. 2007). Historically, livestock in the Teso system are confined to kraals near homesteads for safety against theft in the night and little consideration is given to use of manure as a nutrient resource for fertility maintenance (Mahadevan and Parsons 1970). Such management contributes to soil fertility heterogeneity in the smallholder farms (Augustine 2003; Giller et al. 2006) and inefficient use of nutrients from manure. Even when farmers appreciate the soil fertility improvement role of manure, farm labour constraints curtail redistribution to crop production fields. Some farmers attempt to distribute manure within the proximity of the homestead by moving cattle to new kraals once the current ones are full (Walaga et al. 2000). After some time, the old kraal (niches of high fertility) can be planted with vegetables and cereals like maize for roasting. Variability in soil fertility is also further reinforced by the nutrient mining of the cropping fields.

\section{Farming system productivity associated management and challenges to improve}

Crop productivity of the Teso system was poorer compared to the Mali system (Table 7). The respective productivity levels of cotton, millet and sorghum were 12 , 31 and 59\% higher in Mali and as expected, crop-level nutrient balances are also 


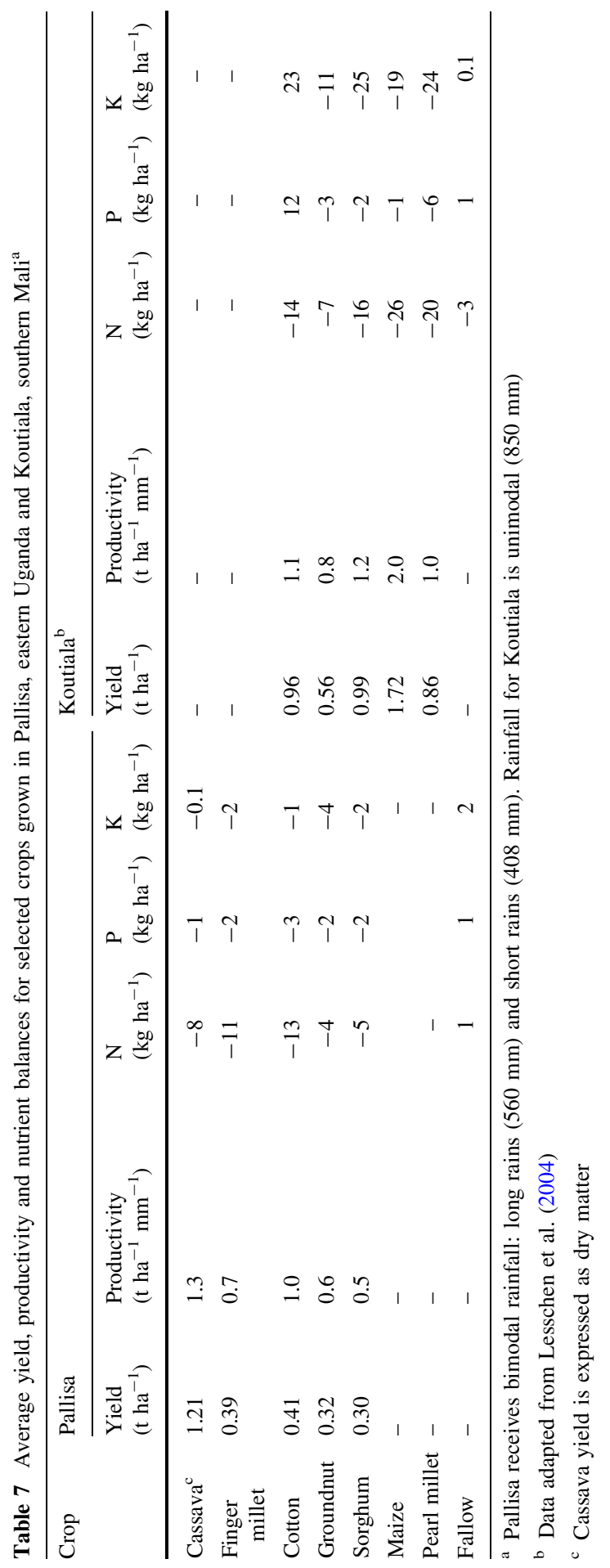


accordingly more negative because of higher removal in products and losses through leaching and erosion (Lesschen et al. 2004). The exception, however, is cotton which received more $\mathrm{P}$ and $\mathrm{K}$ from fertilisers and manure inputs than are lost from the system. The higher productivity of the Mali system could be explained by the stable long rainy season of 5 months compared with shorter bi-modal rainfall seasons (4 and 3 months) in Pallisa, and better soil fertility resulting from continuous nutrient application over a long-term as a result of the market-oriented cotton production. The capital accumulation at household level (cattle), access to input credit and improved production skills because of extension support make farmers in Mali to produce higher crop yields. Further, they were motivated by the assured markets. This demonstrates that soil fertility is considered by farmers when they have tangible direct benefits because often farmers are not interested in improving soil fertility for its sake. In this system, since soils are of poor quality (Kanté 2001), it is worth investing in soil fertility improvement to gain higher returns especially when the nutrient inputs are accessible. The extension support to the farmers also improved their skills in use of manure and fertilisers. The farmers practice target application of the nutrient resources (manure and fertilisers) to the high value crop cotton and the cereals grown in rotation benefit from their residual effects. Farmers have also adopted maize, a high value crop and apply manure directly to it compared to other cereal crops (Kanté 2001; Lesschen et al. 2004).

Over $90 \%$ of the farmers in the Teso farming system reported that both food and cash crop production had declined over the years. They associated the trends in crop production to declining soil fertility, unreliable rainfall and infestation by pest and diseases in the case of food crops but also included lack of agricultural inputs and fluctuating markets in the case of cotton production (Table 8). Farmers (88\%) judged declines in crop yields to be due to presence of striga $(57 \%)$, tired soils (44\%) and stunted crops (1\%), all indicators that have been used by other smallholder farmers in east Africa as well (Mango 1999; Murage et al. 2000). Continuous cultivation without adequate nutrient replenishment is known to account for declining productivity. Often, cultivating improved crop varieties without any soil fertility improvement results in low yields (Kaizzi et al. 2004) and continued nutrient depletion. From this Table, it should also be noted that there are between site differences in farmer responses implying that intervention efforts should take such into account.

The farming systems hardly use external inputs but mainly rely on locally available nutrient input resources. In this section, proportionate uses of practices by households obtained from the survey are discussed and presented in brackets. Crop production is characterised by crop rotation (over 90\%), recycling of crop residues (78\%), fallowing (51\%) and negligible use of nutrient inputs such as cattle manures. The common types of crop residues available are cereal straws, and peelings of cassava and sweet potato. Households also reported that residues face other competitive uses as fodder $(60 \%)$, fuel $(51 \%)$, thatching materials $(5 \%)$, mulching or are just burnt (57\%). The remainder that is recycled is quantitatively small and qualitatively poor, which makes the residues of limited value to be used for soil fertility improvement. High labour requirements (41\%), limited application skills $(35 \%)$ and limited available quantities (32\%) constrain widespread and efficient use 
Table 8 Reasons for declines in food and cash crop production by village in Pallisa district, Uganda

\begin{tabular}{|c|c|c|c|c|c|}
\hline \multirow[t]{2}{*}{ Reason for decline in } & \multicolumn{3}{|c|}{ Percent respondents } & \multirow[t]{2}{*}{ Average } & \multirow[t]{2}{*}{$\chi^{2}$} \\
\hline & $\begin{array}{l}\text { Chelekura A } \\
(n=25)\end{array}$ & $\begin{array}{l}\text { Onamudian } \\
(n=26)\end{array}$ & $\begin{array}{l}\text { Keria } \\
(n=30)\end{array}$ & & \\
\hline \multicolumn{6}{|l|}{ Food crops } \\
\hline Soil infertility & 84 & 73 & 83 & 80 & $* * *$ \\
\hline Unreliable rainfall & 44 & 54 & 43 & 47 & $* * *$ \\
\hline Pests and diseases & 8 & 39 & 13 & 20 & $* * *$ \\
\hline Limited land & 16 & 12 & 23 & 17 & $* * *$ \\
\hline Lack of improved seed & 20 & 19 & 0 & 12 & $* * *$ \\
\hline Inadequate labour & 4 & 4 & 0 & 3 & Ns \\
\hline $\begin{array}{l}\text { Lack of knowledge } \\
\text { and skills }\end{array}$ & 0 & 4 & 0 & 1 & Ns \\
\hline Cash crops & $(n=28)$ & $(n=23)$ & $(n=29)$ & $(n=80)$ & \\
\hline Soil exhaustion & 57 & 57 & 79 & 65 & Ns \\
\hline Lack of agricultural inputs & 30 & 54 & 14 & 33 & $* * *$ \\
\hline Pests and diseases & 26 & 36 & 17 & 26 & $* * *$ \\
\hline Fluctuating market & 9 & 25 & 31 & 23 & $* * *$ \\
\hline Labour intensive & 9 & 14 & 17 & 14 & $* * *$ \\
\hline Lack of improved seed & 17 & 11 & 10 & 13 & $* * *$ \\
\hline Limited land & 9 & 14 & 7 & 10 & $* * *$ \\
\hline $\begin{array}{l}\text { Limited knowledge } \\
\text { and skills }\end{array}$ & 4 & 18 & 0 & 8 & $* * *$ \\
\hline
\end{tabular}

*** Significant at $P<0.001$, Ns Not significant

of cattle manure whereas poverty $(53 \%)$ and negative perceptions that inorganic fertilizers spoil soils (52\%), constrain the use of these. The latter perception arises from campaigns by environmentalists and organic farming advocates. The survey results have similarities with other smallholder farming systems in the low potential areas in sub-Saharan Africa (Hilhorst and Muchena 2000; Nkonya et al. 2005).

Fertility management including practices such as organic matter (cattle manure) cycling, crop rotation and nutrient conservation (sheet erosion control) declined over time in the area. The available quantity of cattle manure, a major source of nutrients is limited following the extensive rustling in the area. Tethering is now the common cattle management system as only few animals are kept. Thus fields receive only little manure input during stubble and dry season grazing. The option of increasing manure production by increasing cattle numbers now faces a great challenge as there are no adequate pastures.

Also other management practices for improving productivity face challenges. Crop rotation was practiced mainly by farmers who have large land sizes and rotations are not well designed to benefit the subsequent crops. In the 1950-1960's, the management recommendation in this system was cropping for 2 years, followed by 3-4 years of fallowing designed in such a way to gradually cover the entire farm with time (Parsons 1970). Legumes were a key component of the rotations 
(Uchendu and Anthony 1975). During the fallow phases, manure deposition through livestock grazing also contributed to nutrient accumulation in such fields (Joblin 1960). Nowadays, the fallow phase is so short, i.e. less than 6 months on $70 \%$ of the farms surveyed. Some farmers equate a field with cassava, the last crop in the rotation cycle for 0.5-2 years, to a resting phase (cassava fallow), a practice also reported in the West African savannas (Kristjanson et al. 2002; Adjei-Nsiah et al. 2007). The 'cassava fallow' is assumed to recycle nutrients through the large biomass produced by the early maturing varieties grown and the grass that grows in the fields during the 1-2 years of cropping. In reality, these high yielding cassava varieties remove substantial amounts of nutrients hence further degrading soils (Fermont et al. 2007).

Lack of implementation of land management policies contribute to degradation of soil fertility in smallholder farms. In the colonial times, the district bylaws and ordinances were implemented by chiefs and fines were attributed for failure to adhere (Kamugisha 1993). In the low lands of the eastern region that includes Pallisa, grass bunds ('amatuta') of $1 \mathrm{~m}$ between fields of $110 \mathrm{~m} \times 65 \mathrm{~m}$ along contours were a requirement to control sheet erosion and bush burning was prohibited (Parsons 1970). The grass bunds are now no longer effectively managed and explain the increased prevalence of sheet erosion during the rainy seasons. In summary, lack of input and output markets and lack of extension support accelerated nutrient depletion in the system and hence widespread negative nutrient balances reported in the system (Wortmann and Kaizzi 1998; Walaga et al. 2000; Nkonya et al. 2005).

\section{Farm household determinants of farm sustainability}

In Table 9, regressions between the characteristics across farm types and major nutrients showed that tropical livestock units (TLU) were the major determinant of balances and nutrient balance to stock ratios (NBSR) for the three major nutrients. For the NBSR, however, crop yields and access to off-farm income especially for $\mathrm{N}$ and $\mathrm{K}$ were also important. These results are expected because cattle are a major source of nutrient inflows to the farms through grazing. Farms with higher livestock numbers (LF) would therefore be expected to have better nutrient balances and NBSR due to accumulation of nutrients in manure from the cattle. In the case of NBSR, however, higher crop yields reduce the amounts of nutrients in the stocks and reflect a situation in which more nutrients are taken out of the farm. Thus farms that produce and sell larger amounts of produce (LF) would end up with smaller NBSR. Access to off-farm incomes would probably reduce the farm areas cultivated or increase investing in farming practices that would improve nutrient accumulation such as growing more legumes.

At the crop scale, however, nutrient balances and NBSR are generally dependent on crop yields and TLU densities. Higher crop yields make nutrient balances more negative knowing that the farmers do not apply any nutrients to crops. The contribution of the cattle is through free range grazing on the farms fields. Labour limited farms, or farms with higher consumer to labour (CL) ratios, can allocate less labour to cultivation of land leading to less negative balances as only low crop 


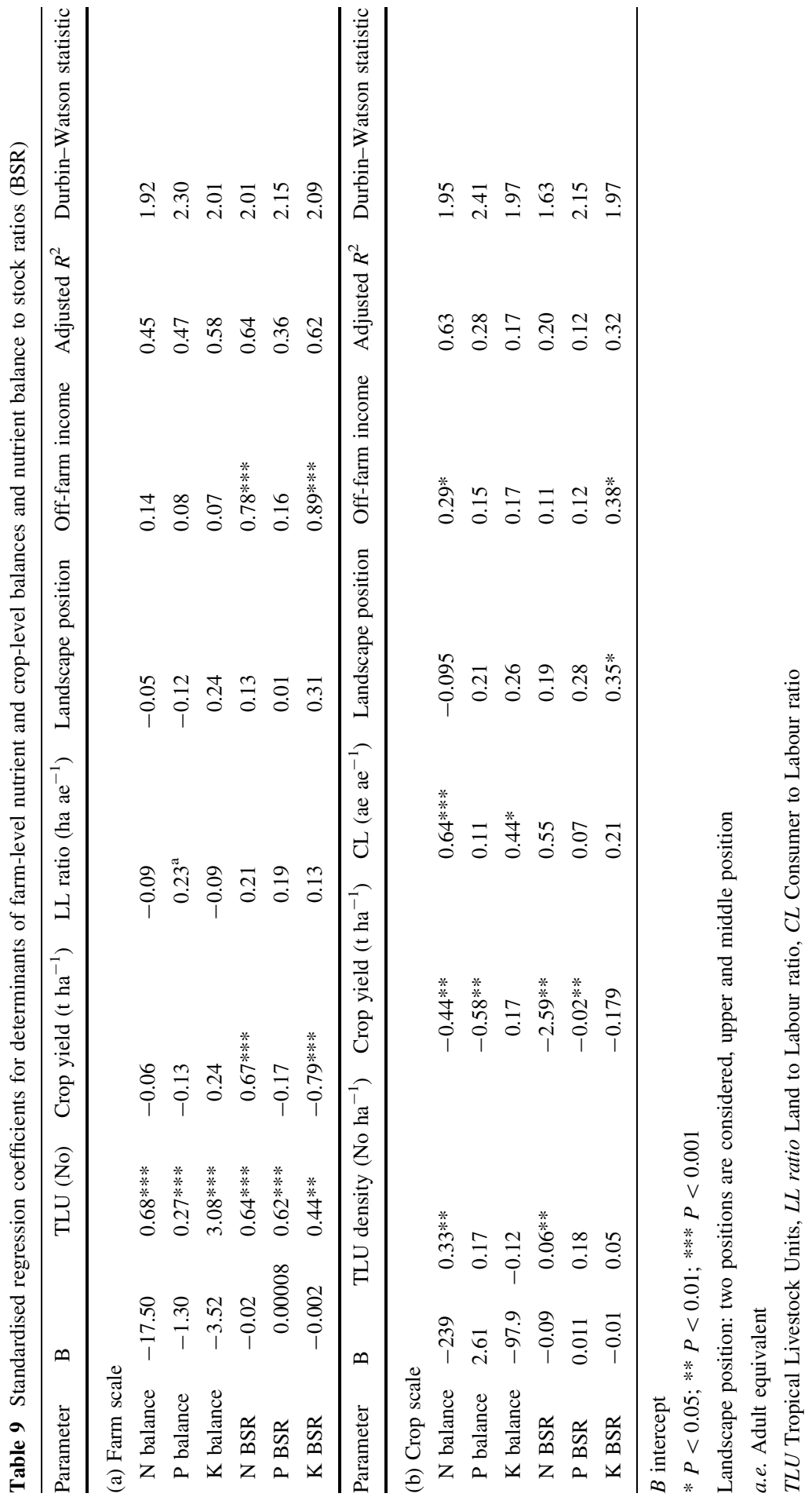


yields are produced. Such farm households are food insecure. Field observations show that the labour limited farms try to plant much land but planting is then late in most of the fields and labour limitations affect weeding resulting in very low yields. The conditions of high CL ratios have been created because of the universal primary education policy which has opened opportunities for many children to go to school. Normally, they form the bulk of family labour. Without any communal or group labour arrangements, cash is needed to buy in labour for farm operations, which is a challenge for the poor households.

The scenario sketched here highlights a need for crop-livestock integration, particularly in manure management to enhance crop production in the case of farms with livestock. This would also boost the NBSR at the crop level and improve the systems sustainability. Improving opportunities for access to off-farm income could relieve pressure from land or could help purchase nutrient inputs which could help in improving nutrient balances and NBSR.

\section{Conclusions}

Land use and productivity status in the Teso farming system changed during the four decades of analysis. Next to population growth, land use change was driven by interactions of political instability that increased insecurity, collapse of input and output markets, and weakened land management and extension service delivery institutions. In response to these external shocks resulting from episodes of political instability, smallholders diversified from millet and cotton to production of cassava, now the dominant crop for food security and cash, and rice for cash and other legumes like groundnuts. Rice cultivation expanded into the swamps faster when the cattle that used to be grazed there were depleted through rustling during the late 1980s. Productivity of the farming system is low as no external nutrient inputs are used and nutrient balances are negative at the crop scale because of nutrient mining. Sustainability of the farming system is determined by numbers of livestock, levels of crop production, labour availability and access to off-farm income.

The example of cotton-cereal farming system in southern Mali shows that improving soil fertility and productivity of farming systems hinges on how it is supported over the long term. Building institutional partnerships around profitable crops can be an entry point for improving soil fertility (Lesschen et al. 2004) but ought to focus on improving livelihood security of the smallholders to gain acceptance and to be sustained. Potential case-specific commercial commodities and viable partnerships for these systems therefore need to be identified and established. It should, however, be noted that population growth in the Malian system during the period considered for analysis in this study (14-64 person $\mathrm{km}^{-2}$ ) was far below that in Pallisa, eastern Uganda. In Mali, there was room to expanding the area of cultivated land at the same time as use of manure and fertilisers to boost crop yield. In the Ugandan system the only realistic trajectory for improving productivity is intensification. Such low input systems will initially need subsidies to boost productivity with external inputs before farmers can find appropriate economic options (de Wit 1992). 
For agronomic improvement of farm productivity, LF farm types may need to use manure in crop production but also improve its management. Since labour can be a major constraint in use of manure, for example transport and application on fields, labour saving approaches are needed. Establishing kraals directly on fields as is done in parts of Zambia (Penninkhoff 1990) accumulates manure directly on fields that are later cultivated. This practice could be adopted by farmers rather than continually maintaining kraals close to homesteads. However, there is need for complementary strategies of making fertilisers available and accessible to smallholder farmers. Creation of opportunities for off-farm income could help a majority of the farm households to acquire nutrient inputs such as fertilisers to apply to the most responsive soils on their farms. Opportunities also exist through growing of leguminous crops to improve soil fertility, especially increasing nitrogen supply through biological nitrogen fixation if other limitations like low $\mathrm{P}$ in soils are addressed (Smithson and Giller 2002; Vanlauwe and Giller 2006). Differential management practices by farmers over years together with inherent characteristics of soils contribute to soil fertility variations in smallholder farms. Improving the farmer's strategy of matching crop production with soil fertility variations (Carter and Murwira 1995) is necessary. This practice has been shown to lead to increased resource use efficiencies (labour and nutrient inputs) in some African farming systems (Zingore 2006; Tittonell 2007) and may aid development of contextspecific management recommendations that can lead to boosting productivity of smallholder systems - the best fits approach (Vanlauwe et al. 2007).

Acknowledgements We thank Dr. Gilbert Majaliwa Mwanjalolo and Ms. Betty Abong for assistance in the land use/land cover analysis; Patrick Okiring, Nakalet Opolot, Lydia Igune, Giregon Olupot, Godfrey Taulya and Joseph Etyang for data collection during the field surveys. Frances Amulen, Philip Okiria and Oulo-Omagor for organising and facilitation of the farmer field schools. The farmers are appreciated for their invaluable collaboration. This study was financed by European Union through INMASP project (CT-2001-10053) and by the Rockefeller Foundation through the INSPIRE II project.

Open Access This article is distributed under the terms of the Creative Commons Attribution Noncommercial License which permits any noncommercial use, distribution, and reproduction in any medium, provided the original author(s) and source are credited.

\section{References}

Adjei-Nsiah, S., Kuyper, T. W., Leeuwis, C., Abekoe, C. K., \& Giller, K. E. (2007). Evaluating sustainable and profitable cropping sequences with cassava and four legume crops: Effects on soil fertility and maize yields in the forest/savannah transitional agro-ecological zone of Ghana. Field Crops Research, 103(2), 87-97.

Anderson, J. M., \& Ingram, J. S. I. (Eds.). (1993). Tropical soil biology and fertility. A handbook of methods (2nd ed.). Wallingford, UK: CAB International.

Augustine, D. J. (2003). Long-term, livestock-mediated redistribution of nitrogen and phosphorus in an East African savanna. Journal of Applied Ecology, 40(1), 137-149.

Awa, A. A., Goromela, E. Z., Okurut-Akol, H., Sembiring, H., Spilsbury, J., \& Touza, A. L. (1999). Towards better integration of livestock and crops in the Teso farming system. Working Document Series 79. ICRA, Wageningen, The Netherlands and SAARI, Soroti, Uganda. 
Baijukya, F. P., de Ridder, N., Masuki, K. F., \& Giller, K. E. (2005). Dynamics of banana-based farming systems in Bukoba district, Tanzania: Changes in land use, cropping and cattle keeping. Agriculture, Ecosystems \& Environment, 106(4), 395-406.

Benjaminsen, T. A. (2001). The population-agriculture-environment nexus in the Malian cotton zone. Global Environment Change, 11(4), 283-295.

Berry, S. (1993). No condition is permanent: The social dynamics of agrarian change in Sub Saharan Africa. University of Wisconsin Press.

Bingen, R. J. (1998). Cotton, democracy and development in Mali. The Journal of Modern African Studies, 36(2), 265-285.

Boserup, E. (1965). The conditions of agricultural growth. London: Earthscan.

Braun, A. R., Thiele, G., \& Fernandez, M. (2000). Farmer field schools and local agricultural committees: Complementary platforms for integrated decision making in sustainable agriculture. Agren Network Paper 105. Overseas Development Institute, London.

Browder, J. O., Pedlowski, M. A., \& Summers, P. M. (2004). Land use patterns in the Brazillian Amazon: Comparative farm level evidence from Rondônia. Human Ecology, 32(2), 197-224.

Carr, S. (1982). The impact of government intervention on smallholder development in North and East Uganda. ADU Occasional Paper 5. Wye College, University of London, London.

Carter, S. E., \& Murwira, H. K. (1995). Spatial variability in soil fertility management and crop response in Mutoko Communal Area, Zimbabwe. Ambio, 24(2), 77-84.

Cleaver, K., \& Schrieber, G. A. (1994). Reversing the spiral. The population, agriculture and environment nexus in sub-Saharan Africa. Directions in development. Washington: The World Bank.

Crowley, E. L., \& Carter, S. E. (2000). Agrarian change and the changing relationships between toil and soil in Maragoli, western Kenya (1900-1994). Human Ecology, 28(3), 383-414.

De Jager, A., Nandwa, S. M., \& Okoth, P. F. (1998). Monitoring nutrient flows and economic performance in African farming systems (NUTMON). I. Concepts and methodologies. Agriculture Ecosystems and Environment, 71(1/2), 37-48.

de Wit, C. T. (1992). Resource use efficiency in agriculture. Agricultural Systems, 40, 125-151.

Defoer, T., \& Budelman, A. (2000). In T. Defoer, \& A. Budelman (Eds.), Managing soil fertility in the tropics. A resource guide for participatory learning and action research. London: Royal Tropical Institute: Amsterdam/International Institute for Environment and Development.

Dixon, J., Gulliver, A., \& Gibbon, D. (2001). Farming systems and poverty. Improving farmers' livelihoods in a changing world. Rome and Washington: FAO and World Bank.

Ebanyat, P. (2009). A road to food? Efficacy of nutrient management options targeted to heterogeneous soilscapes in the Teso farming system Uganda. PhD Thesis. Wageningen University, Wageningen.

Ebanyat, P., Bekunda, M., \& de Jager, A. (2003). Integrated nutrient management to attain sustainable productivity: Participatory diagnosis of constraints and opportunities for soil fertility management in Keria, Chelekura and Onamudian villages, Pallisa District. INMASP Project Report No. MU-05, March 2003. Agricultural Economic Research Institute, Wageningen, The Netherlands, Available at: http://www.inmasp.nl. Accessed March 2005.

Fearnside, P. M. (2000). Global warming and tropical land-use change: Greenhouse gas emissions from biomass burning, decomposition and soils in forest conservation, shifting cultivation and secondary vegetation. Climatic change, 46(1/2), 115-158.

Fermont, A. M., Obiero, H. M., van Asten, P. J. A., Baguma, Y., \& Okwuosa, E. (2007). Improved cassava varieties increase the risk of soil nutrient mining: An ex-ante analysis for western Kenya and Uganda. In A. Bationo (Ed.), Advances in integrated soil fertility management in Sub-Saharan Africa: Challenges and opportunities. The Netherlands: Springer.

Geist, H. J., \& Lambin, E. F. (2002). Proximate causes and underlying forces of tropical deforestation. BioScience, 52(2), 143-150.

Giller, K. E., Rowe, E. C., de Ridder, N., \& van Keulen, H. (2006). Resource use dynamics and interactions in the tropics: Scaling up in space and time. Agricultural Systems, 88(1), 8-27.

Government of Uganda. (1962). Atlas of Uganda (1st ed.). Entebbe: Department of Lands and Surveys. Government of Uganda. (1965). Background to the budget, 1965/1966. Kampala: Ministry of Finance.

Government of Uganda. (1967). Statistical Abstract 1966, Statistics Division. Kampala: Ministry of Planning and Economic Development.

Government of Uganda. (1972). Budget speech. Kampala: Ministry of Finance.

Government of Uganda. (1996). Background to the budget 1996/1997. Kampala: Ministry of Finance and Economic Planning. 
Haileslassie, A., Priess, J. A., Veldkamp, E., \& Lesschen, J. P. (2007). Nutrient flows and balances at the field and farm scale: Exploring effects of land-use strategies and access to resources. Agricultural Systems, 94(2), 459-470.

Hamandawana, H., Nkambwe, M., Chanda, R., \& Eckardt, F. (2005). Population driven changes in land use in Zimbabwe's Gutu district of Masvingo province: Some lessons from recent history. Applied Geography, 25(3), 248-270.

Harrop, J. (1970). Soils. In J. D. Jameson (Ed.), Agriculture in Uganda. Oxford: University Press Oxford.

Hilhorst, T., \& Muchena, F. M. (Eds.). (2000). Nutrients on the move-soil fertility dynamics in African farming systems. London: International Institute for Environment and Development.

Howeler, R. H. (2002). Cassava mineral nutrition and fertilization. In R. J. Hillocks, J. M. Thresh, \& A. C. Bellotti (Eds.), Cassava: Biology, production and utilization. Wallingford: CABI.

Joblin, A. D. H. (1960). The influence of night grazing on the growth rates of zebu cattle in east Africa. Journal of British Grasslands Society, 15, 212-215.

Jongman, R. H. G., Ter Braak, C. J. F., \& Van Tongeren, O. F. R. (Eds.). (1995). Data analysis in community and landscape ecology. Cambridge: Cambridge University Press.

Kaizzi, C. K., Ssali, H., \& Vlek, P. L. G. (2004). The potential of velvet bean (Mucuna pruriens) and N fertilisers in maize production on contrasting soils and agroecological zones of east Uganda. Nutrient Cycling in Agroecosystems, 68(1), 59-72.

Kamugisha, J. R. (1993). Management of natural resources and environment in Uganda: Policy and legislation landmarks 1890-1990. Kampala: Regional Soil Conservation Unit, Swedish International Development Authority.

Kamusuko, C., \& Aniya, A. (2007). Land use/cover change and landscape fragmentation analysis in the Bindura District, Zimbabwe. Land Degradation and Development, 18, 221-233.

Kanté, S. (2001). Gestion de la Fertilité des Sols par Classe d'Exploitation au Mali-Sud. Tropical Resource Management Papers 38. Wageningen University, Wageningen.

Keys, E., \& McConnell, W. J. (2005). Global change and the intensification of agriculture in the tropics. Global Environmental Change, 15, 320-337.

Kidoido, M. M., Kasenge, V., Mbowa, S., Tenywa, J. S., \& Nyende, P. (2002). Socioeconomic factors associated with finger millet production in eastern Uganda. African Crop Science Journal, 10, 111120.

Kristjanson, P., Okike, I., Tarawali, S. A., Kruska, R., Manyong, V. M., \& Singh, B. B. (2002). Evaluating adoption of new crop-livestock-soil management technologies using georeferenced village-level data: the case of cowpea in the dry savannahs of West Africa. In C. B. Barrett, F. Place, \& A. A. Aboud (Eds.), Natural resource management in African Agriculture: Understanding and improving current practices. Wallingford: CAB International.

Lambin, E. F., Geist, H. J., \& Lepers, E. (2003). Dynamics of land-use and land-cover change in tropical regions. Annual Reviews of Environment and Resources, 28, 205-241.

Lambin, E. F., Turner, B. L., Geist, H. J., Agbola, S. B., Angelsen, A., Bruce, J. W., et al. (2001). The causes of land-use and land-cover change: Moving beyond the myths. Global Environmental Change, 11, 261-269.

Lesschen, J. P., Stoorvogel, J. J., \& Smaling, E. M. A. (2004). Scaling nutrient balances: Enabling mesolevel applications for African realities. Report No 15. FAO, Rome.

Mahadevan, P., \& Parsons, D. J. (1970). Livestock. In J. D. Jameson (Ed.), Agriculture in Uganda. Oxford: Oxford University Press.

Malmberg, B., \& Tegenu, T. (2007). Population pressure and dynamics of household livelihoods in an Ethiopian village: An elaboration of the Boserup-Chayanovian framework. Population and Environment, 29(2), 39-67.

Malthus, T. R. (1989). An essay on the principle of population. Cambridge: Cambridge University press.

Mango, N. A. R. (1999). Integrated soil fertility management in Siaya district, Kenya. Managing Africa Soils No 7. International Institute of Environment and Development, London.

Murage, E. W., Karanja, N. K., Smithson, P. C., \& Woomer, P. L. (2000). Diagnostic indicators of soil quality in productive and non-productive smallholders' fields of Kenya's central highlands. Agriculture, Ecosystems \& Environment, 79(1), 1-8.

McMaster, D. N. (1962). A subsistence crop geography of Uganda. Geographical Publications Limited Bude.

Ministry of Agriculture Animal Industries and Fisheries. (1993). Statistical abstracts. Ministry of Agriculture Animal Industries and Fisheries, Entebbe. 
Ministry of Agriculture Animal Industries and Fisheries. (2003). Statistical abstracts. Ministry of Agriculture Animal Industries and Fisheries, Entebbe.

Ministry of Agriculture and Cooperatives. (1963). Report on Uganda Census of Agriculture. Government Printer, Entebbe.

Ministry of Agriculture and Cooperatives. (1966). Report on Uganda Census of Agriculture. Vol (III), Crops. Government Printer, Entebbe.

Ministry of Finance Planning and Economic Development. (1990). Statistical bulletin No GDP/2. Gross domestic product of Uganda 1981-1989. Ministry of Finance Planning and Economic Development, Kampala.

Ministry of Lands, Water and Environment. (2002). National biomass study. Kampala: Ministry of Lands, Water and Environment, Forest Department.

National Environment Management Authority. (2001). The State of Environment Report for Uganda. National Environment Management Authority, Kampala.

Nepstad, D. C., Adalberto Verõ Âssimo, A., Alencar, A., Nobre, C., Lima, E., Lefebvre, P., et al. (1999). Large-scale impoverishment of the Amazonian forests by logging and fire. Nature, 398, 505-508.

Nkonya, E., Kaizzi, C., \& Pender, J. (2005). Determinants of nutrient balances in a maize farming system in eastern Uganda. Agricultural Systems, 85, 155-182.

Ollier, C. D., \& Harrop, J. (1959). The soils of eastern province of Uganda. Memoirs of the Research Division, Soil series No 2. Department of Agriculture, Government of Uganda.

Ollier, C. D., Lawrence, C. J., Beckett, P. H. T., \& Webster, R. (1969). Terrain classification and data storage, land use systems of Uganda. M.E.X.E. Report No 959. University of Oxford, Christchurch.

Parsons, D. J. (1970). Agricultural systems. In J. D. Jameson (Ed.), Agriculture in Uganda. London: Oxford University Press.

Penninkhoff, P. (1990). Cattle manure in the farming systems of western province: Practices and possibilities. Mongu: ARPT.

Perz, S. G. (2001). Household demographic factors as life cycle determinants of land use in the Amazon. Population Research and Policy Review, 20(3), 159-186.

Pichón, F. J. (1997). Settler households and land use patterns in the Amazon frontier: Farm level evidence from Ecuador. World Development, 25(1), 67-91.

Siren, A. H. (2007). Population growth and land use intensification in a subsistence-based indigenous community in the Amazon. Human Ecology, 35(6), 669-680.

Smaling, E. M. A. (1993). An agroecological framework for integrated nutrient management with special reference to Kenya. $\mathrm{PhD}$ Thesis. Wageningen Agricultural University, Wageningen.

Smithson, P. L., \& Giller, K. E. (2002). Appropriate farm practices for alleviating N and P deficiencies in low nutrient soils of the tropics. Plant and Soil, 245(1), 169-180.

Ssali, H., Kabuye, F., Byalebeka, F. B., \& Olani, N. (2002). Enhancement of smallholder farm productivity through sustainable land management in Pallisa District: Appraisal report. Kawanda Agricultural Research Institute, Kampala.

Tappan, G., \& McGahuey, M. (2007). Tracking environment dynamics and agricultural intensification in southern Mali. Agricultural Systems, 94(1), 38-51.

Tefft, J. (2004). Mali's white revolution: Smallholder cotton from 1960 to 2003. 2020 Vision for Food, Agriculture and Environment. Brief 5. IFPRI, Washington.

Thorner, D. Kerblay, B., Smith, R. E. F (eds) (1986). A.V. Chayanov on the theory of peasant economy. Madison: Wisconsin Press.

Tiffen, M., Mortimore, M., \& GIchuki, F. (1994). More people less erosion: Environmental recovery in Kenya. Chechester: Wiley.

Tittonell, P. (2007). Msimu wa Kupanda—targeting resources within diverse, heterogeneous and dynamic farming systems of East Africa. PhD Thesis. Wageningen University, Wageningen.

Tittonell, P., Rufino, M.C., Pacini, C. (2005). AfricaNUANCES database-Data collection protocol for rapid system characterisation. Working paper 3 , version 2 . Available at: http://www.africanuances.nl. Accessed June 2006.

Tukahirwa, J. M. B. (1996). Status and trends in soil and water conservation in Uganda. In M. M. Tenywa \& M. A. Bekunda (Eds.), Proceedings of the workshop on the past, present and prospects of soil and water conservation in Uganda. Kampala: Soil and Water Conservation Society.

Uchendu, V. C., \& Anthony, K. R. M. (1975). Agricultural change in Teso District, Uganda. Mimeo, Nairobi.

Uganda Bureau of Statistics. (1999). Statistical abstract. Uganda Bureau of Statistics, Entebbe.

Uganda Bureau of Statistics. (2004). Statistical abstract. Uganda Bureau of Statistics, Entebbe. 
Uganda Bureau of Statistics. (2005). 2002 Uganda population and housing census. Pallisa District Report. Uganda Bureau of Statistics, Entebbe.

Uganda Investment Authority. (2002). Cotton Sector Overview. Kampala: Uganda Investment Authority. Van der Pol, F., \& Traore, B. (1993). Soil nutrient depletion by agricultural production in southern Mali. Fertilizer Research, 36, 79-90.

Vanlauwe, B., \& Giller, K. E. (2006). Popular myths around soil fertility management in sub-Saharan Africa. Agriculture, Ecosystem \& Environment, 116(1/2), 34-46.

Vanlauwe, B., Mapfumo, P., Baijukya, F., \& Giller, K. E. (2007). Best-fits for heterogeneous farming systems in Africa: A new research agenda. In A. Bationo, J. M. Okeyo, B. S. Waswa, P. Mapfumo, F. Maina, \& J. Kihara (Eds.), Innovations as key to the green revolution in Africa: Exploring the scientific facts, A. Symposium Abstracts: Innovations as a key to the green revolution in Africa: Exploring the Scientific facts. TSBF Afnet, Nairobi.

VanWey, L. K., D’Antona, A. O., \& Brondizió, E. S. (2007). Household demographic change and landuse/landcover change in the Brazillian Amazon. Population and Environment, 28(3), 163-185.

Vlaming, J., van den Bosch, H., van Wijk, M. S., de Jager, A., Bannink, A., \& van Keulen, H. (2001). Monitoring nutrient flows and economic performance in tropical farming systems (NUTMON). Part 1: Manual for the NUTMON-Toolbox. Wageningen: Alterra and LEI.

Vlek, P. L. G. (1990). The role of fertilisers in sustaining agriculture in sub-Saharan Africa. Fertiliser Research, 26, 327-339.

Walaga, C., Egulu, B., Bekunda, M., \& Ebanyat, P. (2000). Impact of policy change on soil fertility management in Uganda. In T. Hilhorst \& F. Muchena (Eds.), Nutrients on the move-soil fertility dynamics in African farming systems. London: International Institute for Environment and Development.

Walker, R., Perz, S., Caldas, M., \& Silva, L. G. T. (2002). Land use and land cover change in forest frontiers: The role of household life cycles. International Regional Science Review, 25, 169-199.

Wortmann, C. S., \& Eledu, C. A. (1999). Uganda's agroecological zones: A guide for planners and policy makers. Kampala: CIAT.

Wortmann, C. S., \& Kaizzi, C. K. (1998). Nutrient balances and expected effects of alternative practices in farming systems of Uganda. Agriculture, Ecosystems \& Environment, 71(1), 115-129.

Yost, D., \& Eswaran, H. (1990). Major land resource areas of Uganda. Washington: The World Bank.

Zingore, S. (2006). Exploring diversity within smallholder farming systems in Zimbabwe: Nutrient use efficiencies and resource management strategies for crop production. $\mathrm{PhD}$ Thesis. Wageningen University, Wageningen. 